\title{
Defensins: antifungal lessons from eukaryotes
}

\author{
Patrícia M. Silva, Sónia Gonçalves and Nuno C. Santos* \\ Instituto de Medicina Molecular, Faculdade de Medicina, Universidade de Lisboa, Lisbon, Portugal
}

\section{Edited by:}

Octavio Luiz Franco, Universidade Católica de Brasilia, Brazil

\section{Reviewed by:}

Valdirene Moreira Gomes, Universidade Estadual do Norte Fluminense, Brazil

Françoise Gosti, Centre National de la Recherche Scientifique, France

\section{*Correspondence:}

Nuno C. Santos, Instituto de Medicina Molecular, Faculdade de Medicina Universidade de Lisboa, Avenida Professor Egas Moniz, 1649-028 Lisbon, Portugal

e-mail:nsantos@fm.ul.pt
Over the last years, antimicrobial peptides (AMPs) have been the focus of intense research toward the finding of a viable alternative to current antifungal drugs. Defensins are one of the major families of AMPs and the most represented among all eukaryotic groups, providing an important first line of host defense against pathogenic microorganisms. Several of these cysteine-stabilized peptides present a relevant effect against fungi. Defensins are the AMPs with the broader distribution across all eukaryotic kingdoms, namely, Fungi, Plantae, and Animalia, and were recently shown to have an ancestor in a bacterial organism. As a part of the host defense, defensins act as an important vehicle of information between innate and adaptive immune system and have a role in immunomodulation. This multidimensionality represents a powerful host shield, hard for microorganisms to overcome using single approach resistance strategies. Pathogenic fungi resistance to conventional antimycotic drugs is becoming a major problem. Defensins, as other AMPs, have shown to be an effective alternative to the current antimycotic therapies, demonstrating potential as novel therapeutic agents or drug leads. In this review, we summarize the current knowledge on some eukaryotic defensins with antifungal action. An overview of the main targets in the fungal cell and the mechanism of action of these AMPs (namely, the selectivity for some fungal membrane components) are presented. Additionally, recent works on antifungal defensins structure, activity, and cytotoxicity are also reviewed.

\section{Keywords: antimicrobial peptides, defensins, antifungal, resistance, host defense peptides}

\section{INTRODUCTION}

Naturally occurring antimicrobial peptides (AMPs) probably represent one of the first successful forms of chemical defense of eukaryotic cells against bacteria, protozoa, fungi, and viruses (Ganz and Lehrer, 1998; Lehrer and Ganz, 1999; Zasloff, 2002; Mookherjee and Hancock, 2007; Lai and Gallo, 2009; Guo et al., 2012; Domingues etal., 2014), being also active against cancer cells (Hoskin and Ramamoorthy, 2008; Gaspar et al., 2013). Currently commercialized antibiotics are mostly of microbial origin or synthesized from those. These antibiotics are losing efficacy as a result of high selection pressure, leading to rapid emergence of resistance in many important human pathogens, thus threatening to put an end to the golden age of antibiotics (Clardy et al., 2009; Fisher etal., 2012). The use of antifungal treatments has increased as a consequence of the increase of immunocompromised patients, mostly due to improvements in oncology and transplant fields (Mehra etal., 2012), leading to more frequent resistances to the drugs used. A strategy to overcome this problem can be found in AMPs, which are part of the innate immune system of different living organisms (Hegedus and Marx, 2013), such as plants (Thomma et al., 2002; Lay and Anderson, 2005; Gonçalves et al., 2012b), fungi (Mygind etal., 2005; Schneider et al., 2010; Oeemig et al., 2012), bacteria (Zhu, 2007; Gao et al., 2009), invertebrates (Bulet and Stocklin, 2005; Ayroza et al., 2012), and vertebrates (Ganz, 2004; Sahl etal., 2005; van Dijk etal., 2008; Gonçalves etal., 2012a).
Although some AMPs have had their target unveiled, many are still unclear. Some mechanisms of action of antifungal peptides have been reported, such as binding to the cell wall, membrane permeabilization, receptor-mediated internalization inducing signaling cascades, and interaction with intracellular targets, inducing the formation of reactive oxygen species (ROS), leading ultimately to apoptosis (Hancock and Rozek, 2002; Oberparleiter et al., 2003; Thevissen et al., 2003a, 2004; de Coninck et al., 2013; van der Weerden et al., 2013). Apoptosis is a type of programed cell death, which is regulated by a complex network of proteins and metabolic pathways. The central core of this process is regulated by a family of proteins named caspases. Yeasts have at least one ortholog of mammalian caspases: the metacaspase YCA1 (yeast caspase 1; Madeo et al., 2002). Routinely used assays aiming at the detection of these apoptotic features are used for the identification of fungal cells undergoing apoptosis after treatment with antifungal agents.

Antimicrobial peptides have variable amino acid composition and size (ranging from less than 10 to more than 100 amino acid residues), commonly being cationic and amphipathic molecules (Brogden etal., 1996; Yang etal., 2003; Fontana et al., 2004; Glaser et al., 2005; Domingues et al., 2014). To date, more than 2200 natural or synthetic AMPs have been identified, as listed by the Antimicrobial Peptide Database $\left(\mathrm{APD}^{1}\right)$, of which over 1900 have antibacterial activity and 800 have antifungal activity.

\footnotetext{
${ }^{1}$ http://aps.unmc.edu/AP/main.php
} 
This discrepancy, however, may be redundant as antibacterial AMPs may also have antifungal activity, but this property is not systematically assessed.

Antimicrobial peptides may have linear structures, like indolicidin (Ladokhin et al., 1999), or they may have tertiary structures stabilized by disulfide bonds, with $\beta$-sheet (e.g., protegrin; Aumelas etal., 1996; and the defensin human neutrophil peptide 1, HNP-1; Zhang et al., 2011), $\alpha$-helix (e.g., dermaseptin; Mor etal., 1991) or $\alpha \beta$-motif secondary structure (e.g., drosomycin; Landon et al., 1997; and Pisum sativum defensin 1, Psd1; Almeida et al., 2002).

The most studied families of AMPs are cathelicidins, dermaseptins, magainins, cecropins, and defensins. Cathelicidins are found in the innate immune system of mammals, amphibians, and reptiles (Wang et al., 2008; Tsai et al., 2011; Hao et al., 2012); dermaseptins and magainins are found in amphibians (Morton etal., 2007); cecropins are found in insects (YiZeng et al., 1989); and defensins, which are the largest family of AMPs, have also the broader distribution across the majority of eukaryotic organisms (Wang et al., 2013). Besides having antimicrobial activity, defensins also have immunomodulatory functions in the organisms that produce these peptides. Defensins with antifungal properties are present in all eukaryotic kingdoms, pointing out to a common ancestor. This review is focused on defensins (as well as some defensin-like peptides) with antifungal activity. However, it is impossible to describe here all the defensins with this activity. Therefore, we highlight some of the most recent research made on this field. The chosen peptides are described taking into consideration their specific properties, evolutionary background, organism of origin, and antifungal mode of action.

Some databases have been created in order to provide useful information for the study of AMPs. Among the AMP databases, PhytAMP is a database dedicated to antimicrobial plant peptides $^{2}$ (Hammami et al., 2009). This resource contains valuable information on these AMPs, including peptide sequences, taxonomic, microbiological, and physicochemical data. Another database, Collection of Anti-Microbial Peptides $\left(\mathrm{CAMP}^{3}\right)$, holds

\footnotetext{
${ }^{2}$ http://phytamp.pfba-lab-tun.org/main.php

${ }^{3} \mathrm{http}: / /$ www.camp.bicnirrh.res.in/
}

experimentally validated and predicted AMP sequences and structures of AMPs. These databases include several tools for AMPs analysis and prediction, helping in the design of new therapeutic peptides based on specific structure and functional features.

\section{DEFENSINS}

Defensins are the largest groups of AMPs. These peptides are cysteine-rich and have diverse sequences and structures, stabilized into compact shapes by three or four conserved cysteine disulfide bridges. They have at least two positive charges (lysine or arginine residues) and are small, ranging approximately from 12 to 50 amino acid residues (2-6 kDa; Ganz, 2003; Ren et al., 2011; Gao and Zhu, 2012).

Vertebrates' defensins are divided into three subfamilies: $\alpha-, \beta$-, and $\theta$-defensins. $\alpha$-Defensins are present in mammals such as humans, monkeys, and several rodent species, being particularly abundant in neutrophils, certain macrophage subpopulations and Paneth cells of the small intestine (Ouellette and Selsted, 1996; Ganz and Lehrer, 1998; Lehrer and Ganz, 1999). $\beta$-defensins are found in a wide range of vertebrates, presenting a cysteinestabilized $\alpha \beta$-motif composed of an antiparallel $\beta$-sheet and an $\alpha$-helix. As an example, on bovine neutrophils, as many as 13 $\beta$-defensins have been identified (Yang et al., 2002a). However, in other species, $\beta$-defensins are mostly produced by epithelial cells lining different organs (e.g., epidermis, bronchial tree, and genitourinary tract). $\theta$-Defensins, present only in Old World monkeys, are cyclic and derived from $\alpha$-defensins (Lehrer, 2004; Lehrer and Lu, 2011; Semple and Dorin, 2012). In Figure 1, conserved cysteine residues among defensins from different kingdoms are shown.

Plants, fungi, and many invertebrates produce defensin-like peptides structurally similar to the $\beta$-defensins from vertebrates (Thomma et al., 2002; Bulet and Stocklin, 2005; Mygind et al., 2005; Sahl et al., 2005; Yount and Yeaman, 2006; van Dijk et al., 2008; Ayroza etal., 2012; Oeemig et al., 2012). These observations allowed to assume that defensins and defensin-like peptides all evolved from a common precursor. The relatively recent identification of three defensins in lower eukaryotes, plectasin from Pseudoplectania nigrella (Mygind et al., 2005), eurocin from Eurotium amstelodami (Oeemig et al., 2012), and bubble protein

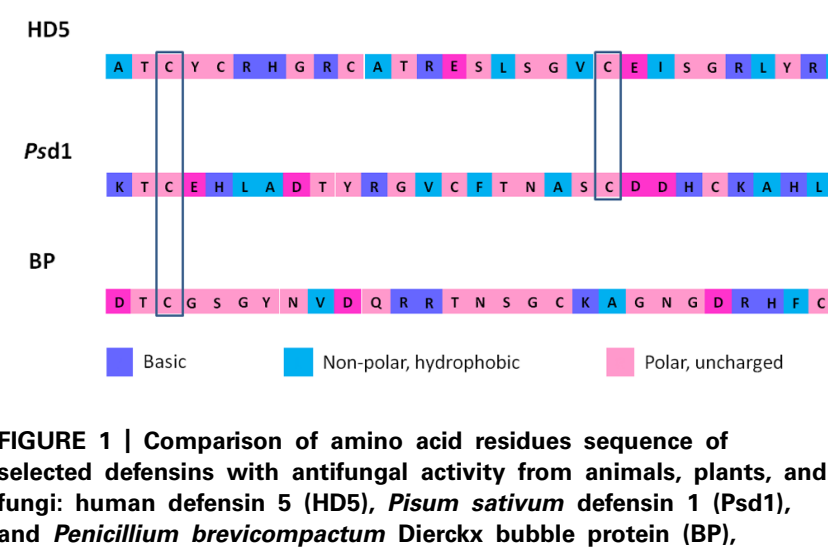

selected defensins with antifungal activity from animals, plants, and and Penicillium brevicompactum Dierckx bubble protein (BP), respectively. Conserved cysteine residues among defensins from different kingdoms are indicated. The colors used in the sequences represent basic, non-polar hydrophobic, polar-uncharged and acidic residues. 
(BP) from Penicillium brevicompactum Dierckx (Seibold et al., 2011), is important to demonstrate the wide distribution of these peptides over diverse eukaryotic lineages, which suggests that ancestral defensin genes existed over 1500 million years ago, before Fungi, Plantae, and Animalia kingdoms diverged (Wang et al., 1999). The wide distribution of these peptides in the Eukarya domain could suggest their uniqueness to eukaryotic cells, but it was possible to determine that these peptides may have had their ancestor in a prokaryotic organism after the discovery of the first defensin-like peptide in the bacteria Anaeromyxobacter dehalogenans (AdDLP; Zhu, 2007; Gao et al., 2009). This defensin-like peptide is proposed as an ancestor of eukaryotic defensins and defensin-like peptides due to the similarity of their structures, namely at the level of the cysteine-stabilized $\alpha \beta$-motif (Zhu, 2007). These findings further support the concept that AMPs may have been fundamental to the evolution of multicellular organisms within microbial-exposed environments.

Although defensins were initially identified only as AMPs, recent studies have demonstrated that they have a much broader range of action, including immunomodulatory function (issue further developed in the text, in Section "Immunomodulatory Function"; Ulm et al., 2012).

\section{RECENTLY STUDIED ANTIFUNGAL DEFENSINS}

When a new AMP is described, the most usual properties to assess are structure and peptide sequence, antimicrobial activity, expressed mainly in terms of minimal inhibitory concentration (MIC) or half maximal inhibitory concentration $\left(\mathrm{IC}_{50}\right)$, cytotoxicity and lytic activity against human cells (whenever the AMP origin is not mammalian), target, and mode of action toward the pathogen tested. The following AMPs were classified as defensins or defensin-like peptides due to their structural and sequence homologies with other defensins. They are examples of some of the recently studied antifungal defensins from fungal, plant, and animal origin that fulfill most of the properties expressed above. Further details and a list of some of these defensins can be found in Table 1.

\section{FUNGAL SOURCES}

Defensin-like antifungal peptides secreted by filamentous fungi have a low molecular mass $(5.8-6.6 \mathrm{kDa})$, a basic character, presence of 4-10 cysteine residues and several disulfide bonds (providing resistance against temperature stress or adverse solvent conditions), and a $\beta$-barrel conformation (Hagen etal., 2007; Seibold etal., 2011). Proteins with such properties with antifungal activity have been isolated and investigated from several Ascomycota fungal species, such as Penicillium chrysogenum, Penicillium nalgiovense, Penicillium brevicompactum Dierckx, Aspergillus giganteus, and Aspergillus niger (Galgóczy et al., 2010; Seibold et al., 2011). Among these fungus-derived antifungal peptides, the most intensively studied are Penicillium chrysogenum antifungal protein (PAF) and Aspergillus giganteus antifungal protein (AFP), with six and eight cysteines, respectively. Penicillium brevicompactum Dierckx bubble protein structure is considerably similar to PAF and AFP.

\section{Penicillium chrysogenum antifungal protein}

PAF acts through a $G$ protein-coupled signal transduction pathway, although this mechanism is not entirely understood (Marx et al., 2008). The G protein-coupled activity of PAF was confirmed by the study of the fadA mutant of Aspergillus nidulans which proved to be less sensitive to PAF treatment compared to the wild-type. The fadA gene encodes the heterotrimeric G protein $\alpha$ subunit, which dissociation from the $G_{\beta \gamma}$ complex is inhibited in the fadA mutant Aspergillus nidulans (Leiter et al., 2005). These results indicate that PAF toxicity requires active heterotrimeric G protein signaling (Leiter et al., 2005; Marx et al., 2008). Based on these observations, Marx et al. (2008) hypothesized that PAF interacts directly or indirectly with $G$ protein signal transduction pathways. These authors also hypothesized that the cell wall could be a selective barrier for PAF, but in vivo chitin-binding activity of PAF has not been demonstrated yet. In the sensitive organisms, PAF exerts multiple detrimental effects: induction of plasma membrane polarization, increased exposure of phosphatidylserine (PS) on the cell surface, DNA fragmentation, membrane blebbing, cell shrinking, intracellular ROS production, and apoptosis-like phenotype (Kaiserer et al., 2003; Leiter et al., 2005; Marx et al., 2008).

\section{Aspergillus giganteus antifungal protein}

In susceptible organisms, AFP disturbs the polarized growth of hyphae by interfering directly or indirectly with the cell wall biosynthesis (Theis et al., 2003). Hagen et al. (2007) demonstrated that AFP can bind to chitin in vitro, and inhibits the cell wall chitin biosynthesis by the specific inhibition of chitin synthase III and $\mathrm{V}$. These enzymes are unique among fungi and essential for the maintenance of the polarized growth and virulence of pathogenic fungi. Presence of chitin synthase III and V is confirmed in the AFP-sensitive fungi, while the insensitive fungal species do not have these enzyme classes. Sphingolipid membrane components in the sensitive fungi might serve as secondary receptors for AFP. This was further confirmed by the discovery that the depletion of cellular glucosylceramide (GlcCer) levels in AFP-sensitive fungal species (Aspergillus fumigatus and Aspergillus niger) resulted in reduced AFP susceptibility (Meyer, 2008). This, together with the observation that the sphingolipids are necessary to maintain the polarized hyphal growth, elucidates the mechanism of polarized growth degeneration effect of AFP (Li et al., 2006; Meyer, 2008). The species specificity of AFP may be related with the sphingolipid profile of the sensitive fungi (Meyer, 2008).

\section{Penicillium brevicompactum Dierckx bubble protein}

This fungal defensin was first described in 2003 (Olsen et al., 2004). It is found in the bright yellow-green fluorescent exudate bubbles of the ascomycete fungus Penicillium brevicompactum Dierckx. Similarly to other ascomycetes, BP produces a small antimicrobial molecule, mycophenolic acid, which gives the bubbles their yellow-green fluorescence. This combined production suggests a possible synergistic action between defensins and other antibiotic agents produced by this class of fungi (Seibold et al., 2011). BP has 64 amino acid residues, with high content of basic amino acids, $\beta$-barrel conformation (Olsen et al., 2004), and a cage-like pattern of four very stable disulfide bridges. In addition, it was discovered 


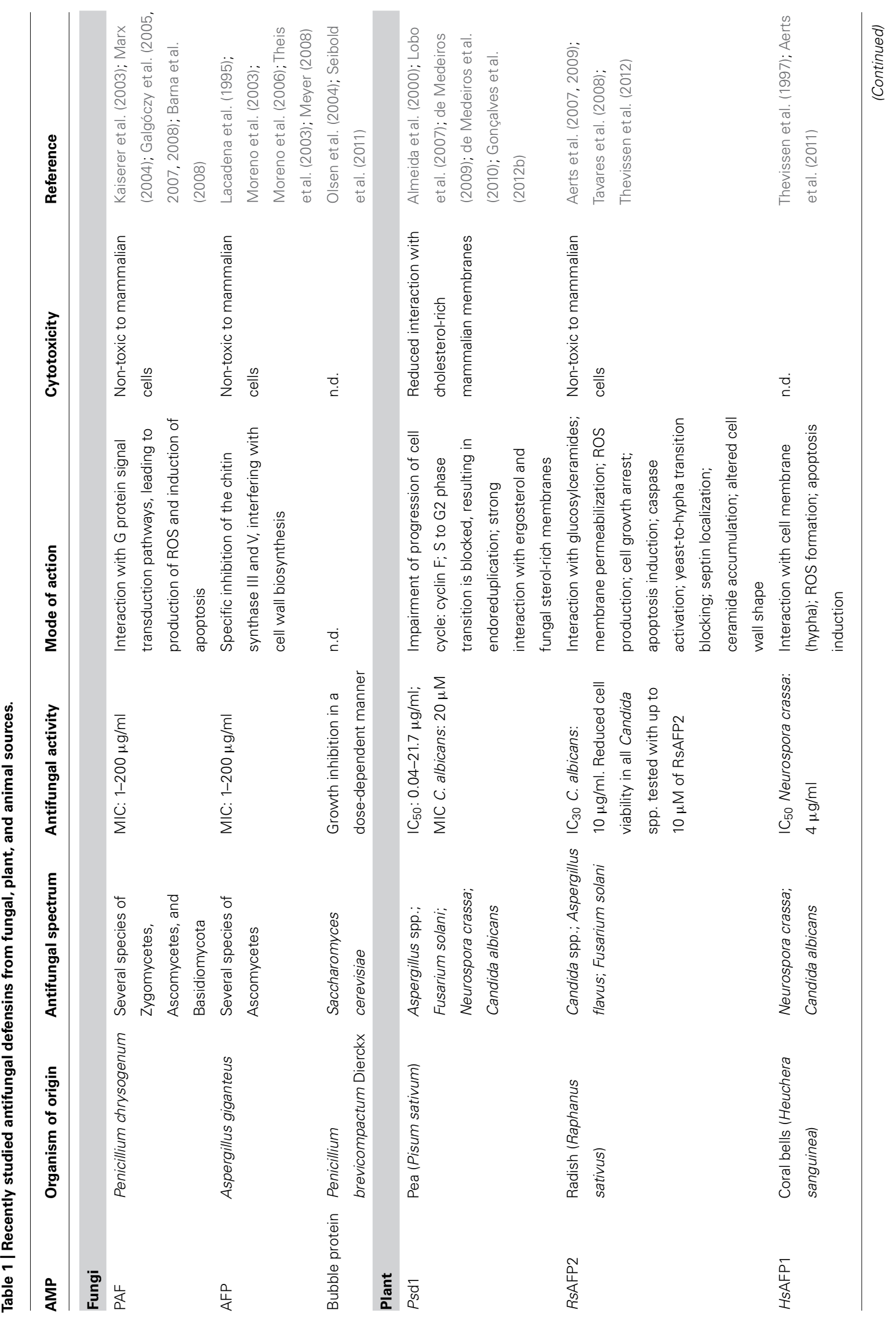




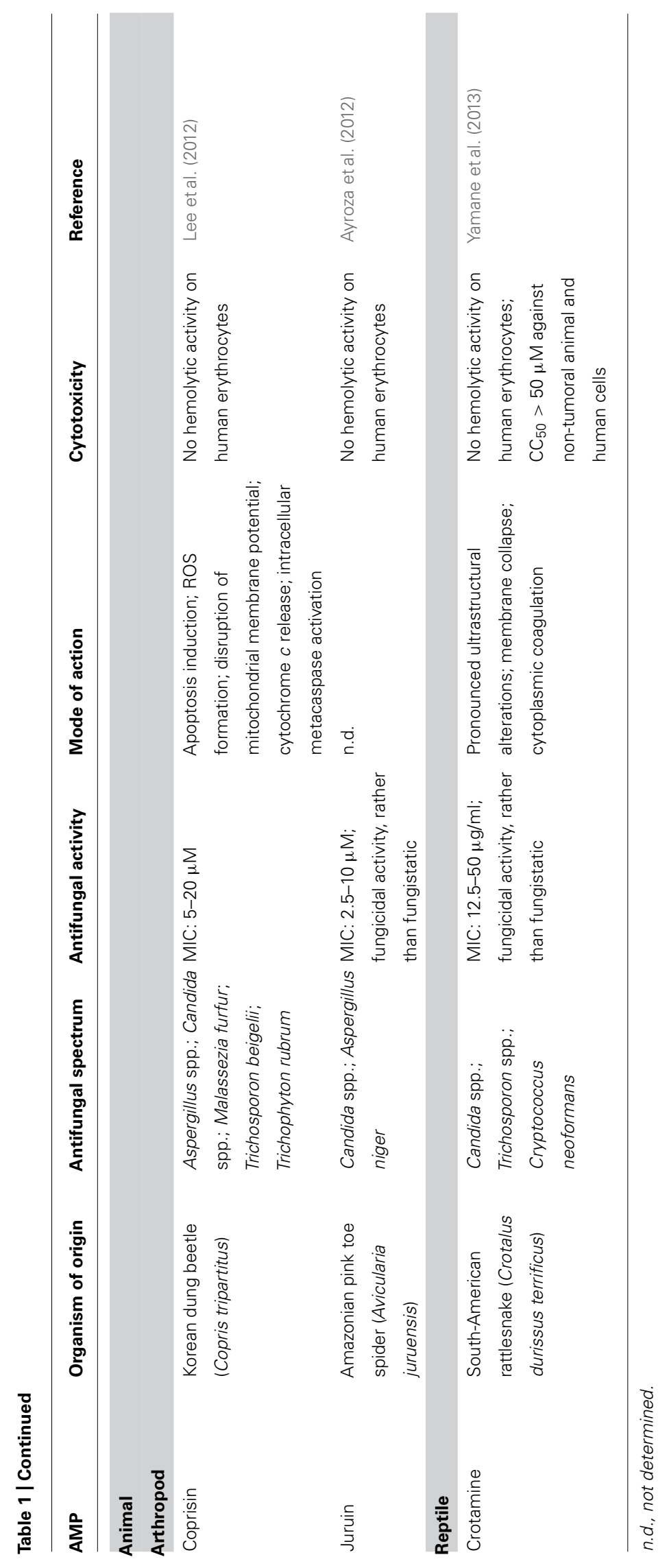


that the closely related fungus Penicillium chrysogenum encodes a $\mathrm{BP}$ homolog (in addition to PAF), indicating that fungi may have more than one defensin (Seibold et al., 2011).

\section{PLANT SOURCES}

Many fungi are phytopathogenic, with species such as Fusarium spp., Cladosporium spp., Pythium spp., Curvularia spp., Aspergillus flavus, and Puccinia pittieriana affecting potato, rice, corn, wheat, tobacco, and cotton crops by causing wilt, mold, crown rot, mildew, and rust, just to name a few plant diseases (The American Phytopathological Society, $\mathrm{APS}^{4}$ ). These diseases can deplete entire crops, bearing enormous costs for agriculture due to the difficulty in eliminating fungal infections from plants, once they appear. Soils harbor plants for most of their life cycle, but also a considerable amount of bacteria, fungi, and parasites, many of which can be phytopathogenic. For this reason, plants need to have good defenses against these microorganisms; thus, it is easy conceivable that plants are major AMPs producers, often with antifungal activity, but also antibacterial activity (Moreno et al., 1994; Segura et al., 1998; Thomma et al., 2002; Mayer et al., 2013).

In fact, a major research effort has been put forward on the screening for these molecules in plants. Besides defensins, other AMPs are also produced by plants, being exclusive to them. Examples of these plant exclusive AMPs are thionins, lipid transfer proteins and snakins, which were also demonstrated to have antifungal activity (Segura et al., 1999; Silverstein et al., 2007; Sun et al., 2008; Asano et al., 2013). Plant defensins with antifungal activity have been purified from several plants, such as Pisum sativum (Almeida etal., 2000; Lobo et al., 2007; de Medeiros, 2009; de Medeiros et al., 2010; Gonçalves et al., 2012b), Raphanus sativus (Aerts et al., 2007, 2009; Tavares et al., 2008; Thevissen et al., 2012), and Heuchera sanguinea (Thevissen et al., 1997; Aerts et al., 2011), which will be addressed below. Several other plant defensins with antifungal activity have also been studied. Specific information about some of those defensins can be found on the following references: Medicago sativa defensin $1(M s$ Defl) and Medicago truncatula defensin 4 (MtDef4; Spelbrink et al., 2004; Ramamoorthy et al., 2007a,b; Sagaram et al., 2011); Dahlia merckii AMP 1 (DmAMP1; Thevissen et al., 1999, 2000a,b, 2003b; Jha et al., 2009; Salahinejad et al., 2013); Phaseolus vulgaris defensin 1 (PvD1; Games et al., 2008; Mello et al., 2011; Wu et al., 2011; Chan et al., 2012; Wong et al., 2012; Chan and Ng, 2013); Nicotiana alata defensin 1 ( $N a D 1$; Lay et al., 2003, 2012; van der Weerden et al., 2008, 2010; Hayes et al., 2013).

\section{Psd1}

This garden pea (Pisum sativum) seed defensin, firstly characterized in 2000 (Almeida et al., 2000), has 46 amino acid residues. Its secondary structure comprises a globular fold composed of $\beta$-sheets and an $\alpha$-helix stabilized by four disulfide bridges, i.e., a cysteine-stabilized $\alpha \beta$-motif (Almeida et al., 2002). As demonstrated by a yeast two-hybrid screening system, Psd 1 has affinity to a Neurospora crassa protein related to the cell cycle control, cyclin F (Lobo et al., 2007). Using a developing retinal tissue of neonatal

${ }^{4} \mathrm{http} / / /$ www.apsnet.org/ rats as a model to study this interaction, it was proven that Psd1 impairs the correct cell cycle progression, by blocking cyclin F role in the transition of S to G2 phases of the cell cycle, promoting endoreduplication and disturbing nuclear migration. Recently, it has been demonstrated through partition studies that Psd1 has a high affinity with high specificity to model membranes enriched with ergosterol, the main sterol present in fungal membranes, and GlcCer (Gonçalves et al., 2012b). On the contrary, there is no interaction between the defensin and model membranes enriched in cholesterol (a characteristic of mammalian cells), reducing Psd1 toxicity to human cells.

\section{RsAFP2}

This defensin, isolated from radish (Raphanus sativus) seeds in 1992 (Terras et al., 1992), has 51 amino acid residues and is highly cationic. It has eight cysteine residues, forming four disulfide bridges that stabilize its $\alpha \beta$-motif structure. RsAFP2 has fungal GlcCer as its target, as observed in experiments performed with wild-type Candida albicans and a mutant lacking GlcCer in the membrane ( $\Delta g c s$; Aerts et al., 2007). It does not need to be internalized to have its antifungal effect. After the initial contact, a signaling cascade is activated inside the cell and ROS are formed, leading to membrane permeabilization and consequent cell death (Aerts et al., 2007). Other effects of RsAFP2 comprise the induction of apoptosis in C. albicans by triggering caspases activation, but not of metacaspases, implying that different apoptotic pathways can be induced in C. albicans (Aerts et al., 2009). RsAFP2 also promotes an accumulation of ceramides in C. albicans, which can be lethal to the cell, and blocks the yeast-to-hypha transition (Thevissen etal., 2012). In vivo experiments were performed in murine models, proving that RsAFP2 considerably reduces the fungal burden in kidneys of mice infected with $C$. albicans. This defensin has low susceptibility to serum peptidases, meaning that upon entering the bloodstream it will not be degraded, maintaining its antifungal activity. Lactate dehydrogenase (LDH) release levels are indicative of cell damage and tissue breakdown. Human brain endothelial cells incubated with RsAFP2 show no release of $\mathrm{LDH}$, hence supporting the conclusion that this defensin has limited toxicity to mammalian cells.

\section{HsAFP1}

Firstly identified in 1995, this defensin found in the seeds of coral bells plant $H$. sanguinea (Osborn et al., 1995) was shown to have high affinity to specific sites in fungal membranes and to permeabilize cells of susceptible fungi (Thevissen et al., 1997). Unlike RsAFP2, which relies on an interaction with GlcCer to exert its antifungal effect, HsAFP1 has antifungal activity against C. albicans $\Delta g c s$ and its wild-type counterpart (Aerts et al., 2011). It was proposed that HsAFP1 may interact with essential components of the fungal membrane, resulting in a low occurrence of resistance in vitro, an advantage for the use of HsAFP1 as a novel antifungal agent (Aerts et al., 2011). Using sodium azide, a respiratory inhibitor, mitochondrial function is impaired and HsAFP1 antifungal activity is affected, indicating that the defensin requires a properly working respiratory chain. This defensin induces ROS formation and apoptosis in yeast. It was also proposed that mitogen-activated protein kinase (MAPK) signaling pathways may 
be a possible strategy for yeast tolerance to HsAFP1 (Aerts et al., 2011).

\section{ANIMAL SOURCES \\ Mammal defensins}

Antimicrobial peptides from animal sources have shown antifungal and immunomodulatory activities, being mammals major producers of defensins (Yang et al., 2002a,b; Sahl et al., 2005). $\theta$-Defensins are the less studied defensin family, at least partially due to their source. To date, no antifungal activity was attributed to $\theta$-defensins; as such, these defensins will not be further discussed in the present review. Being vertebrates, mammals possess an adaptive immune system, hence having a more complex network of signaling pathways, diverse responses against pathogens invading the organism and an array of AMPs produced in different organs and tissues, each with its particular function and mode of action (Ganz and Lehrer, 1998; Ganz, 2004; Lai and Gallo, 2009; Pasupuleti et al., 2012). Human $\beta$-defensins 1 and 2 are chemotactic for memory $\mathrm{T}$ cells and immature dendritic cells (Pazgier et al., 2006). Mammal defensins differ substantially in their antimicrobial specificities. For example, HNP-1, HNP-5 and human beta-defensins 1 and 3 (HBD1 and HBD3, respectively) have broad antimicrobial activities against Gram-negative and Gram-positive bacteria and yeasts (Ganz et al., 1985; Bensch et al., 1995; Porter et al., 1997; Harder et al., 2001; Hoover et al., 2003; Joly et al., 2004). HBD1 and HBD3 have been shown to be effective against C. albicans (Krishnakumari et al., 2009), while HBD2 has been shown to possess significant microbicidal activity against Gram-negative bacteria and C. albicans (Schroder and Harder, 1999). Recombinant human intestinal defensin 5 (rHD-5) exhibits microbicidal activity against Listeria monocytogenes, Escherichia coli, and C. albicans. Opposed to cryptdins, the mouse intestinal defensins, rHD-5 is active against both mouse-virulent wild-type Salmonella typhimurium and its isogenic, mouse-avirulent pho $\mathrm{P}$ mutant (Porter et al., 1997).

Mouse $\beta$-defensin 3 (MBD3), a HBD2 homolog, is an AMP expressed in the mouse epithelial and mucosal tissues (Jiang et al., 2010). The fungicidal properties of recombinant MBD3 suggest that similar peptide formulations can be used in the treatment of fungal and/or bacterial infections. MBD3 is expressed in footpads, skin, and mucosal membranes (tongue) of normal mice. Potent antifungal activity was observed against filamentous fungi, such as Aspergillus fumaricus, Microsporum canis, Trichophyton rubrum, Trichophyton tonsurans, and Trichophyton violaceum (all these species are primary human pathogens, meaning they cause infection whether or not the immune defenses are weakened, as opposed to opportunistic fungal infections), as well as yeast strains like C. albicans and Cryptococcus neoformans. This peptide also presents bactericidal activity against Gram-positive and Gram-negative bacteria, such as Staphylococcus aureus, E. coli, and Salmonella typhi (Jiang et al., 2010).

\section{Arthropods defensins}

Coprisin. This 43 amino acid residues beetle defensin-like peptide was described in 2009 as an antibacterial peptide (Hwang et al., 2009). Its structure comprises an $\alpha \beta$-motif, stabilized by three cysteine disulfide bridges (Lee et al., 2013). In 2012, the same authors investigated its antifungal activity against C. albicans, revealing that coprisin enters the fungal cell and localizes in the nucleus, which indicates that coprisin penetrated the membrane without disrupting the fungal plasma membrane, as confirmed with 1,6-diphenyl-1,3,5-hexatriene (DPH) analysis, calcein-leakage, and giant unilamellar vesicle assays (Lee et al., 2012). Using $\mathrm{H}_{2} \mathrm{O}_{2}$ as a positive control for apoptotic induction, coprisin proved to have the same effects in inducing early and late apoptosis, features shown by the annexin $\mathrm{V}$ conjugated with fluorescein and propidium iodide co-staining method. Apoptosis induced by this AMP is metacaspase-dependent. Concomitantly, coprisin compromises mitochondrial membrane potential and ROS production, in addition to the release of cytochrome $c$ from the mitochondria to the cytosol. No hemolytic activity was observed for this peptide in human erythrocytes (Lee et al., 2012).

Juruin. This defensin-like peptide was discovered in 2012 by screening the venom on the theraposid Amazonian pink toe spider Avicularia juruensis (Ayroza et al., 2012). It has 38 amino acid residues, three disulfide bonds and, like neurotoxins reported to have antimicrobial activity, it has a putative inhibitory cysteine knot (ICK) motif, i.e., a fold common to venom peptides from spiders, scorpions, and aquatic cone snails (Smith et al., 2011). ICK-containing peptides of spider venom are likely to have evolved from $\beta$-defensins (Fry et al., 2009). Based on amino acid sequence and structure similarities with insecticidal peptides of other spiders, this peptide is likely to belong to a group of conserved toxins with voltage-gated ion channels inhibitory action. Juruin showed a fungicidal rather than fungistatic effect against C. albicans and C. tropicalis, without hemolytic activity (Fry et al., 2009).

\section{Reptile defensins}

Crotamine. This highly basic peptide, isolated from the venom of a South-American rattlesnake, was discovered in 1947 (Gonçalves and Polson, 1947). It shares structural similarity to $\beta$-defensins due to an identical disulfide bridge pattern (Fadel et al., 2005; Yamane et al., 2013). Crotamine structure comprises an antiparallel $\beta$-sheet and an $\alpha$-helix stabilized by three disulfide bridges (Nicastro et al., 2003; Fadel et al., 2005). Recombinant crotamine displayed a more potent antimicrobial activity than native and synthesized crotamine (Yamane et al., 2013). This peptide induces extensive ultrastructural modifications in C. albicans. TEM studies showed deformed cell shape, irregular layering structure of cell wall and cytoplasmic contents coagulation, but without detectable hemolytic effects and low toxicity to mammalian cells (Yamane et al., 2013).

\section{IMMUNOMODULATORY FUNCTION}

Defensins may be produced constitutively or have their expression triggered when there is an inflammatory process, by the recognition of microbial conserved structures, such as lipopolysaccharide (LPS) and lipoteichoic acid, or inflammatory effectors, like cytokines. These AMPs are expressed differentially depending on the peptide itself and on the tissue or cell type (Ulm et al., 2012). Defensins, besides their antimicrobial action, can also be immunomodulatory and inhibitors of virulence factors. This ability is not exclusive of defensins, as other AMPs also 
share this property. Thus, they can enhance the host's immune system, with this multifunctional character rendering these peptides lower probability of becoming tolerated by microorganisms (Mehra et al., 2012; Jarczak et al., 2013).

Pro-inflammatory mediation has been recognized in some of these molecules, as they can bind to chemokine receptors, being able to recruit immune cells, thus enhancing the immune response (Mookherjee and Hancock, 2007; Lai and Gallo, 2009; Alba etal., 2012; Semple and Dorin, 2012; Ulm etal., 2012; Zhu and Gao, 2013). $\beta$-Defensins were demonstrated to have the capability to induce chemoattraction of $\mathrm{CD} 4^{+}$memory $\mathrm{T}$ cells, macrophages, and immature dendritic cells, by binding to receptors in the membrane (Yang et al., 1999; Wu et al., 2003; Taylor et al., 2008). This binding favors the attraction and migration of inflammatory cells to the inflammation site, in order to improve and speed up the inflammatory response. $\alpha$ and $\beta$ Defensins have also been shown to inhibit neutrophil apoptosis (Nagaoka et al., 2008). These authors showed that HBD3 binds to CCR6 at the neutrophil cell surface, initiating an increase in the levels of the antiapoptotic protein Bcl-xL and inhibiting caspase activity. This increases neutrophils life span and is an inflammatory event that is beneficial to eradicate invading microorganisms (Nagaoka et al., 2008), thus promoting the production of proinflammatory cytokines and chemokines, which in turn, amplifies the immune system response. Defensins have been shown to have a proinflammatory effect on human keratinocytes (Niyonsaba etal., 2007). Treatment of these cells with HBD2 HBD3 or HBD4 leads to the increase of the expression of proinflammatory mediators, like monocyte chemoattractant protein1 , macrophage inflammatory protein-3, and some interleukins (Niyonsaba et al., 2007).

Surprisingly, some defensins are also able to attenuate proinflammatory responses whenever these can be harmful to the organism (Lande etal., 2007; Yamasaki etal., 2007). These antagonistic effects depend on the level of expression, disease state, and pathogen exposure. It has been previously described for $\alpha$-defensins that mice having a matrilysin deficiency (hence without mature $\alpha$-defensins in the intestine) are more susceptible to chemically induced colitis than wild-type controls. Interleukin- $1 \beta$ (IL-1 $\beta$ ), a cytokine with an important role in mediation of inflammation, reaches level significantly increased in the deficient mice and it was ultimately shown that $\alpha$-defensins are able to inhibit the production of IL- $1 \beta$ (Shi et al., 2007).

It has been demonstrated that HBD3 (mainly expressed in epithelial cells), when in basal concentration, has an immunosuppressive effect in the presence of LPS, contributing to the maintenance of a non-inflammatory environment over continual low-level exposure to microorganisms, commensal or pathogenic (Semple et al., 2010). Concentrations of HBD3 ranging from 0.5 to $1 \mu \mathrm{M}$ are able to suppress the induction of tumor necrosis factor $\alpha(\mathrm{TNF} \alpha)$, a proinflammatory effector of the immune system, and IL-6, an interleukin that acts both as pro and anti-inflammatory. At these concentrations, proinflammatory proteins are not induced and there is no proinflammatory gene expression (Semple et al., 2010). The proinflammatory effects of $\beta$-defensins were observed at slightly higher concentrations of the defensin, in the $4-6 \mu \mathrm{M}$ range (Funderburg et al., 2007; Niyonsaba et al., 2010). This was not the first case observed of opposite effects in immunomodulating AMPs. Cathelicidin LL-37 has been shown to have also a duality in inflammatory effects, being proinflammatory at concentrations above $20 \mu \mathrm{g} / \mathrm{ml}$ but anti-inflammatory at $1-5 \mu \mathrm{g} / \mathrm{ml}$ (Scott et al., 2002). Defensins were also shown to have a role in other biological processes, namely wound healing (Hirsch et al., 2009), dog coat color determination (Candille et al., 2007), fertility (Li et al., 2001), plant development (Stotz et al., 2009), and carcinogenesis regulation (Donald et al., 2003; Gambichler et al., 2006; Joly et al., 2009).

It is clear that defensins have many functions that are determined by the level of expression. Whereas higher expression of defensins takes place at the pathogen's site of entry, with a proinflammatory response and the chemoattraction of macrophages and other immune cells, defensins expressed at lower levels may be involved in the resolution of the immune response. When the danger is neutralized and defensins and other proinflammatory molecules decrease in the inflammation site, defensins may then have a role in resolving inflammation (Semple and Dorin, 2012).

Due to this multifunctionality, AMPs have also been referred to as host defense peptides (HDPs; Steinstraesser et al., 2010; Ulm et al., 2012).

\section{RESISTANCE}

Like other antibiotics resistance, it is easily conceivable that AMPs resistance is a key characteristic for increased virulence of pathogenic strains. Despite this fact, and contrary to antibiotics that act through a single approach (meaning that microbes can evade them through a single resistance system), AMPs follow a multidimensional strategy against microbial invasion (Lai and Gallo, 2009). Therefore, selective pressures on microbes are avoided, reducing the development of resistant strains (Zasloff, 2002).

A synergistic effect between different host AMPs is also possible, as evidenced by the fact that the MIC of AMPs in vitro are usually higher than the physiological concentrations of those AMPs in vivo (Lai and Gallo, 2009). Two distinct AMPs may have their combined MIC much lower than when acting isolated, strongly suggesting heterologous HDP interactions (Westerhoff et al., 1995).

Microorganisms have evolved their own strategies for evading the antimicrobial action of the compounds used against them. AMPs frequently have the ability to disrupt microbial membranes and to inhibit the synthesis of some of their components; thus, strategies to escape the action of those AMPs follow the redesign of cell membranes, as described for both Gram-negative and Grampositive bacteria (Gunn et al., 2000; Li et al., 2007). Other evasion mechanisms include affecting the correct function of the AMP by turning off its expression, releasing plasmid DNA in epithelial cells, a strategy adopted by highly contagious bacteria from the Shigella genus that cause dysentery (Islam et al., 2001). As AMPs frequently rely on transmembrane potential to interact with microbial pathogens and exert their mechanism of action against them, it is probable that another microbe strategy for evading AMPs could be to change their transmembrane potential status (Yeaman and Yount, 2003). 
Candida albicans resistance to some AMPs is regulated by the protein Ssd1, combined with the transcription factor Bcr1 (biofilm and cell wall regulator; Nobile and Mitchell, 2005; Gank et al., 2008; Jung et al., 2013). Ssd1 is an RNA-binding protein and a component of the regulation of morphogenesis pathway (Saputo et al., 2012). In C. albicans, this pathway governs multiple processes, including filamentation and cell wall integrity (Song et al., 2008; Bharucha et al., 2011). This combination yields resistance to protamine, RP-1 and HBD2 by maintaining mitochondrial energetics and reducing membrane permeabilization, thus allowing the fungus to counteract the negative effects of these AMPs (Jung et al., 2013). Protamine is an $\alpha$-helical cationic polypeptide, frequently used to screen for AMP susceptibility (Yeaman et al., 1996), and RP-1 is a synthetic AMP modeled upon the C-terminal $\alpha$-helical domain existent in the human platelet factor-4 kinocidins; this domain is responsible for RP-1 microbicidal activity (Bourbigot et al., 2009). C. albicans mutant strains in Bcrl and Ssd1 proteins are more susceptible to the AMPs described above; thus, Jung et al. (2013) were able to conclude that these proteins are necessary for the resistance to protamine, RP-1 and HBD2. Further studies are necessary to clarify the roles of Bcrl and Ssd1 in early versus late mechanisms of resistance to AMPs.

The Hog1 (high osmolarity glycerol) MAPK pathway, which provides a response to osmotic, oxidative, and heavy-metal exposure stresses in fungal cells, was shown to be activated in the presence of AMPs, such as NaD1, HBD2, HBD3, and histatin-5 (a salivary cationic AMP that has a role in keeping C. albicans in its commensal state; Yeaman et al., 1996; Vylkova et al., 2007; Argimon et al., 2011; Hayes et al., 2013). The injuries imposed on C. albicans by these defensins seem to share common features with osmotic and/or oxidative stress (Argimon et al., 2011). Upon exposure to these defensins, the Hog1 MAP kinase is activated, triggering a transcriptional response aimed to rescue the cells from the source of injury, i.e., the core and osmotic-stress transcriptional responses (Enjalbert et al., 2006; Argimon et al., 2011).

Another strategy for evading AMP function is to enzymatically degrade these peptides before they exert their effects. This is possible by producing proteases and peptidases involved in tissue degradation, as described for C. albicans secreted aspartic proteases (Saps). Namely, histatin-5, present in human saliva, is a host-specific substrate of Sap9, enabling the transition of the fungus from commensal to pathogenic in $\mathrm{HIV}^{+}$individuals. These patients, who have lower levels of this isoenzyme in the saliva, have an increased incidence of oral candidiasis (Meiller et al., 2009; Khan et al., 2013). Also regarding histatin-5, a transport mechanism of efflux mediated by the flu- 1 transporter has been described for $C$. albicans, rendering the pathogen the ability to reduce the isoenzyme cytosolic concentration and fungicidal activity ( $\mathrm{Li}$ et al., 2013). The LL-37 cathelicidin and histatins bind to cell wall carbohydrates, preventing adhesion of C. albicans to host cells; thus, the release of AMP-binding proteins acts as a decoy for these AMPs, diverting them from binding to fungal cell surface (den Hertog et al., 2005, 2006; Mochon and Liu, 2008). For example, Msb2 (multicopy suppressor of a budding defect) is a $C$. albicans surface protein (a mucin) highly soluble and proteolytically stable, which is shed to the extracellular environment, acting as a basal
AMP-resistance decoy by binding to LL-37 and histatin-5, avoiding the antimicrobial action of these AMPs (Szafranski-Schneider et al., 2012).

The characteristics described above are associated with a decrease in microbes' susceptibility to AMPs, indicating that microbial pathogens have developed some structure-specific and energy-dependent mechanisms to subvert the action of these host defense systems.

\section{FUNGAL CELL MEMBRANE}

Fungi possess a unique cell wall and cell membrane that can serve as specific targets for antifungal agents. The fungal cell membrane is similar to those of other eukaryotic cells, composed of a lipid bilayer with proteins embedded within it (Katzung et al., 2011). Sterols (absent in prokaryotes) are major components of fungal membranes. The sterol present in higher eukaryotic membranes is cholesterol, but in fungal membranes the main sterol present is ergosterol, providing stability and flexibility to the cell membrane (Thevissen et al., 1999, 2003a).

Glycosphingolipids (GSLs) are a family of lipids that act as key components of biological membranes. They exist in animals, plants, and fungi (Leipelt et al., 2001; Halter et al., 2007; Daniotti and Iglesias-Bartolome, 2011). GSLs were initially described as components of the architecture of cell membranes, straightly connected with fluidity and stability (Feinstein et al., 1975; Aaronson and Martin, 1983; Campanella, 1992). Recently, however, it was demonstrated that their role goes clearly beyond the initial concept, since these molecules are major components of specialized membrane domains called lipid rafts (Bagnat et al., 2001; Hakomori, 2003, 2008). GSLs have been characterized as important structures in cell-cell interaction, cell signaling, and protein sorting (Bagnat et al., 2000; Bagnat and Simons, 2002; Nimrichter et al., 2008; Staubach and Hanisch, 2011). Lipid rafts are more ordered and tightly packed than the surrounding bilayer, serving as organizing centers for the assembly of signaling molecules, influencing membrane fluidity and membrane protein trafficking (Chiantia and London, 2013).

The most common GSL found in fungi is GlcCer, present in the membranes of most fungi, such as Pichia pastoris, C. albicans, Cryptococcus neoformans, Aspergillus fumigatus, Sporothrix schenckii and Neurospora crassa (Saito et al., 2006). Large amounts of this GSL have also been found in the fungal cell wall (Nimrichter and Rodrigues, 2011). GlcCer has been identified as a fungal component decades ago. Its functions during fungal growth/dimorphism, lipid raft formation, and correlation with virulence have been reported (Rittershaus etal., 2006). In fact, it was recently shown to be required for virulence in C. albicans (de Medeiros et al., 2010; Noble et al., 2010; de Coninck et al., 2013).

Work published by Thevissen and colleagues strongly suggested that fungal GlcCer targeting by the AMPs RsAFP2 and HsAFP1 could initiate a cell signaling response in fungi, with formation of ROS and subsequent cell death by apoptosis (Thevissen et al., 2004; Aerts et al., 2007, 2009, 2011). The use of anti-GlcCer antibodies was shown to block germ tube formation in C. albicans, Colletotrichum gloeosporioides, and Pseudallescheria boydii (Pinto et al., 2002; da Silva et al., 2004), and also to protect mice upon 
the potentially lethal infection by C. neoformans (Rodrigues et al., 2007).

The crescent knowledge of GlcCer functions in eukaryotes (may these be related to virulence, growth or morphological transitions), together with the findings described above, can be connected to specific and essential structural features and particular biosynthetic steps to validate this GSL, as well as other fungal specific membrane lipids and sterols, as potential targets on the development and discovery of new antifungal drugs (Nimrichter and Rodrigues, 2011; Gonçalves et al., 2012b). Besides GlcCer, fungal membranes are also rich in phosphomannans and in the negatively charged phospholipids PS, phosphatidylinositol (PI) and diphosphatidylglycerol (DPG), which confer a highly negative surface charge to these membranes (Pasupuleti et al., 2012).

\section{MODELS OF MEMBRANE ACTIVITY - MECHANISM OF ACTION}

The biological activity of AMPs is strongly influenced by peptidemembrane interactions. To explain how some AMPs show differential membrane affinity, their biological activities, and modes of action have been assessed on studies of defensins interaction with fungal membrane model systems, which showed a strong dependence on membrane lipid composition and on the concentration of specific components (de Medeiros et al., 2010; Gonçalves etal., 2012a,b). As with other AMPs, the mechanisms of action of some plant defensins with antifungal activity involve membrane binding, binding to the cell wall, interaction with intracellular targets leading to apoptosis, membrane permeabilization, and receptor-mediated internalization (van der Weerden et al., 2013).

The mechanisms of action of some defensins have been studied by using synthetic lipid vesicles mimicking the lipid composition of fungal, bacterial and mammal membranes (de Medeiros et al., 2010; Wimley and Hristova, 2011; Gonçalves et al., 2012a,b). The permeabilization models used to explain the mode of action of defensins could be classified into two main groups: transmembrane pore formation, such as the barrel-stave and toroidal models, and non-pore formation, such as the carpet, aggregate channel, Shai-Matsuzaki-Huang, lipid clustering, and interfacial activity models (Alba et al., 2012). The carpet model can evolve to disrupt the membrane through pore formation models or through a detergent-like mechanism, with partial micellization of the membrane (Bechinger and Lohner, 2006; Chang et al., 2008; Hoskin and Ramamoorthy, 2008). There are currently at least three different commonly accepted models describing possible AMPs mode of action: the barrel-stave pore model, the toroidal pore model, and the carpet model (Shai, 2002; Chang et al., 2008; Hoskin and Ramamoorthy, 2008; Alba et al., 2012).

Most defensins are amphipathic molecules with clusters of positively charged amino acid residues side chains and hydrophobic amino acid side chains (Lehrer and Lu, 2011). This structural behavior allows them to interact with microbial membranes both at the level of the negatively charged phospholipid head groups and of the hydrophobic fatty acid chains. The orientation of the peptide on the membrane surface depends on the specific peptidelipid system, but it is common for the AMP to stay at the membrane interface until a threshold peptide concentration is reached (Yang et al., 2000; Yount and Yeaman, 2005; Pasupuleti et al., 2012). In the barrel-stave model (Figure 2), once the critical threshold concentration of peptide is reached, peptides self-aggregate in the membrane resulting in the formation of a transmembrane pore lined by peptide, which dissipates proton and ionic gradients (Ehrenstein and Lecar, 1977; Reddy et al., 2004), but the membrane thickness and homogeneity do not change (Chang et al., 2008). The toroidal pore model is a variant of the barrel-stave model, claiming that, at some critical peptide concentration, curvature strain induces membranes to curve inward, resulting in the formation of a pore that is lined by both peptides and lipid headgroups (Figure 2). Toroidal pores seem to have varying lifetimes and longer-lived pores may have a lethal effect similar to barrel-stave pores, with dissipation of proton and ion gradients. This type of mechanism of AMPs action also causes a decrease in membrane thickness and a slightly decreased surface homogeneity (Chang et al., 2008). In the carpet model (Figure 2), peptides bind to phospholipid head groups by electrostatic interactions and align themselves parallel to the membrane surface in a carpet-like fashion until a critical threshold concentration is reached. When a detergent-like membrane micellization takes place, a strong decrease of membrane homogeneity occurs (Chang et al., 2008; Hoskin and Ramamoorthy, 2008; Epand et al., 2010; Hazlett and Wu, 2011; Li et al., 2012; Pasupuleti et al., 2012).

Besides targeting fungal membranes' specific components, defensins may also have other mechanisms of action, as previously referred. These mechanisms comprise binding to the cell wall, membrane permeabilization, receptor-mediated internalization inducing signaling cascades and interaction with intracellular targets, which would cause the formation of ROS, leading ultimately to programed cell death. To address these mechanisms the reader is directed to some relevant references on this topic (Hancock and Rozek, 2002; Oberparleiter et al., 2003; Thevissen et al., 2003a, 2004; Schroeder et al., 2011; de Coninck et al., 2013; De

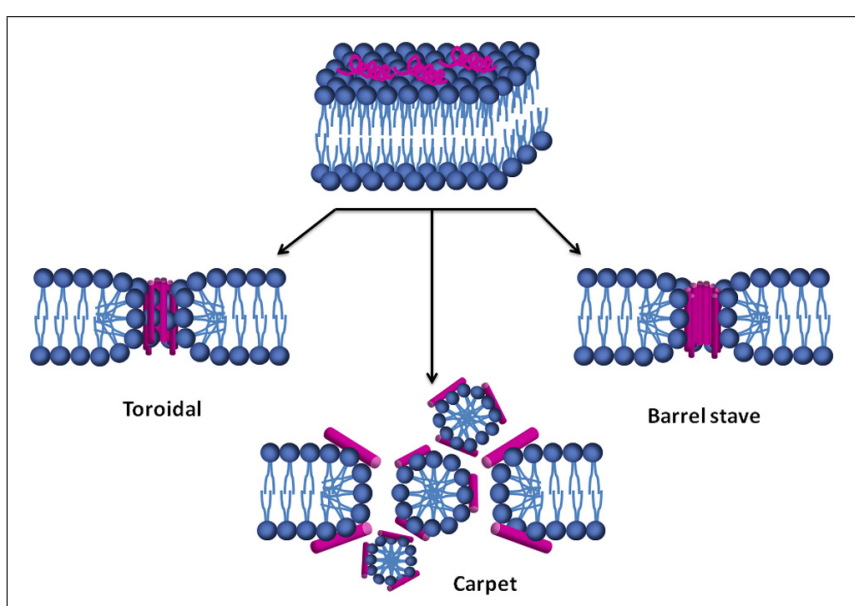

FIGURE 2 | Models of lipid membrane permeabilization by AMPs. Initially, the peptide (magenta) is adsorbed at the membrane surface. After an initial recognition of the surface, a conformational change of the peptide occurs. Once a threshold concentration of peptide on the membrane is reached, it is followed by membrane disruption by one of these three mechanisms. 
Paula et al., 2013; Jaeger et al., 2013; van der Weerden et al., 2013; Zhang et al., 2013).

\section{CONCLUSION}

The knowledge on AMPs has been increasing considerably during the last 20 years. This increased knowledge shows that AMPs have much more than only antimicrobial activity, presenting a broad spectrum of physiological functions. Defensins are the most represented AMPs across the eukaryotic domain, and in all types of eukaryotic organisms we can find defensins not only with antifungal activity but also with other potential applications.

Despite this relevance, defensins may have limitations in terms of new drug development, due to their cationic, amphiphilic, and protease labile nature, leading to a low serum half-life that limits their systemic administration (Maisetta et al., 2008). This limitation can be overcome by the use of peptidomimetics, like the substitution of natural occurring L-amino acid residues by $\mathrm{D}$ amino acid residues or unusual amino acids (Oren et al., 1997; McPhee etal., 2005). Defensins bare a favorable characteristic against this problem, as their disulfide-stabilized structure confers increased protease-resistance (Wu et al., 2003). Nonetheless, defensins combine targeted antimicrobial activity with the capacity to positively modulate the immune system, and have proven to be effective across life evolution, making these peptides highly appealing as an anti-infective strategy.

Defensins have evolved as successful barrier of defense not only against bacteria, but also pathogenic fungi, present among plants, animals, and fungi. This ability may serve as a "lesson" on how selective pressures that shape organisms and their components served and continue to serve as a lever for the evolution of better defenses. Most antibiotics used nowadays are from bacterial origin or synthetic (Clardy et al., 2009; Fisher et al., 2012). The molecular design and synthesis of new molecules inspired on defensins or on other AMP structures and sequences seem to be a promising approach to develop a new and extensive field of applications, ranging from antimicrobial therapy, to their possible use as vaccine adjuvants. Therefore, a better understanding of function and mechanism of action of HDPs, specially defensins, is highly relevant for the development of new anti-infective and immunomodulatory therapeutics (Guaní-Guerra et al., 2013).

\section{ACKNOWLEDGMENTS}

This work was partially supported by Fundação para a Ciência e Tecnologia - Ministério da Educação e Ciência (FCT-MEC, Portugal) and by the European Union FP7-IRSES project MEMPEPACROSS.

\section{REFERENCES}

Aaronson, L. R., and Martin, C. E. (1983). Temperature-induced modifications of glycosphingolipids in plasma membranes of Neurospora crassa. Biochim. Biophys. Acta 735, 252-258. doi: 10.1016/0005-2736(83)90300-0

Aerts, A. M., Bammens, L., Govaert, G., Carmona-Gutierrez, D., Madeo, F., Cammue, B. P., et al. (2011). The antifungal plant defensin HsAFP1 from Heuchera sanguinea induces apoptosis in Candida albicans. Front. Microbiol. 2:47. doi: 10.3389/fmicb.2011.00047

Aerts, A. M., Carmona-Gutierrez, D., Lefevre, S., Govaert, G., François, I. E., Madeo, F., et al. (2009). The antifungal plant defensin RsAFP2 from radish induces apoptosis in a metacaspase independent way in Candida albicans. FEBS Lett. 583, 2513-2516. doi: 10.1016/j.febslet.2009.07.004
Aerts, A. M., François, I. E., Meert, E. M., Li, Q. T., Cammue, B. P., and Thevissen, K. (2007). The antifungal activity of RsAFP2, a plant defensin from Raphanus sativus, involves the induction of reactive oxygen species in Candida albicans. J. Mol. Microbiol. Biotechnol. 13, 243-247. doi: 10.1159/000104753

Alba, A., Lopez-Abarrategui, C., and Otero-Gonzalez, A. J. (2012). Host defense peptides: an alternative as antiinfective and immunomodulatory therapeutics. Biopolymers 98, 251-267. doi: 10.1002/bip.22076

Almeida, M. S., Cabral, K. M., Kurtenbach, E., Almeida, F. C., and Valente, A. P. (2002). Solution structure of Pisum sativum defensin 1 by high resolution NMR: plant defensins, identical backbone with different mechanisms of action. J. Mol. Biol. 315, 749-757. doi: 10.1006/jmbi.2001.5252

Almeida, M. S., Cabral, K. M., Zingali, R. B., and Kurtenbach, E. (2000). Characterization of two novel defense peptides from pea (Pisum sativum) seeds. Arch. Biochem. Biophys. 378, 278-286. doi: 10.1006/abbi.2000.1824

Argimon, S., Fanning, S., Blankenship, J. R., and Mitchell, A. P. (2011). Interaction between the Candida albicans high-osmolarity glycerol (HOG) pathway and the response to human beta-defensins 2 and 3. Eukaryot. Cell 10, 272-275. doi: 10.1128/Ec.00133-10

Asano, T., Miwa, A., Maeda, K., Kimura, M., and Nishiuchi, T. (2013). The secreted antifungal protein thionin 2.4 in Arabidopsis thaliana suppresses the toxicity of a fungal fruit body lectin from Fusarium graminearum. PLoS Pathog. 9:e1003581. doi: 10.1371/journal.ppat.1003581

Aumelas, A., Mangoni, M., Roumestand, C., Chiche, L., Despaux, E., Grassy, G., et al. (1996). Synthesis and solution structure of the antimicrobial peptide protegrin-1. Eur. J. Biochem. 237, 575-583. doi: 10.1111/j.1432-1033.1996.0575p.x

Ayroza, G., Ferreira, I. L., Sayegh, R. S., Tashima, A. K., and da Silva Junior, P. I. (2012). Juruin: an antifungal peptide from the venom of the Amazonian Pink Toe spider, Avicularia juruensis, which contains the inhibitory cystine knot motif. Front. Microbiol. 3:324. doi: 10.3389/fmicb.2012.00324

Bagnat, M., Chang, A., and Simons, K. (2001). Plasma membrane proton ATPase Pmalp requires raft association for surface delivery in yeast. Mol. Biol. Cell 12, 4129-4138. doi: 10.1091/mbc.12.12.4129

Bagnat, M., Keranen, S., Shevchenko, A., and Simons, K. (2000). Lipid rafts function in biosynthetic delivery of proteins to the cell surface in yeast. Proc. Natl. Acad. Sci. U.S.A. 97, 3254-3259. doi: 10.1073/pnas.060034697

Bagnat, M., and Simons, K. (2002). Lipid rafts in protein sorting and cell polarity in budding yeast Saccharomyces cerevisiae. Biol. Chem. 383, 1475-1480. doi: 10.1515/BC.2002.169

Barna, B., Leiter, E., Hegedus, N., Biro, T., and Pocsi, I. (2008). Effect of the Penicillium chrysogenum antifungal protein (PAF) on barley powdery mildew and wheat leaf rust pathogens. J. Basic Microbiol. 48, 516-520. doi: 10.1002/jobm.200800197

Bechinger, B., and Lohner, K. (2006). Detergent-like actions of linear amphipathic cationic antimicrobial peptides. Biochim. Biophys. Acta 1758, 1529-1539. doi: 10.1016/j.bbamem.2006.07.001

Bensch, K. W., Raida, M., Magert, H. J., Schulz-Knappe, P., and Forssmann, W. G. (1995). hBD-1: a novel beta-defensin from human plasma. FEBS Lett. 368, 331-335. doi: 10.1016/0014-5793(95)00687-5

Bharucha, N., Chabrier-Rosello, Y., Xu, T., Johnson, C., Sobczynski, S., Song, Q., et al. (2011). A large-scale complex haploinsufficiency-based genetic interaction screen in Candida albicans: analysis of the RAM network during morphogenesis. PLoS Genet. 7:e1002058. doi: 10.1371/journal.pgen.1002058

Bourbigot, S., Dodd, E., Horwood, C., Cumby, N., Fardy, L., Welch, W. H., et al. (2009). Antimicrobial peptide RP-1 structure and interactions with anionic versus zwitterionic micelles. Biopolymers 91, 1-13. doi: 10.1002/bip.21071

Brogden, K. A., De Lucca, A. J., Bland, J., and Elliott, S. (1996). Isolation of an ovine pulmonary surfactant-associated anionic peptide bactericidal for Pasteurella haemolytica. Proc. Natl. Acad. Sci. U.S.A. 93, 412-416. doi: 10.1073/pnas.93.1.412

Bulet, P., and Stocklin, R. (2005). Insect antimicrobial peptides: structures, properties and gene regulation. Protein Pept. Lett. 12, 3-11. doi: $10.2174 / 0929866053406011$

Campanella, R. (1992). Membrane lipids modifications in human gliomas of different degree of malignancy. J. Neurosurg. Sci. 36, 11-25.

Candille, S. I., Kaelin, C. B., Cattanach, B. M., Yu, B., Thompson, D. A., Nix, M. A., et al. (2007). A $\beta$-defensin mutation causes black coat color in domestic dogs. Science 318, 1418-1423. doi: 10.1126/science. 1147880

Chan, Y. S., and Ng, T. B. (2013). Northeast red beans produce a thermostable and $\mathrm{pH}$-stable defensin-like peptide with potent antifungal activity. Cell Biochem. Biophys. 66, 637-648. doi: 10.1007/s12013-012-9508-1 
Chan, Y. S., Wong, J. H., Fang, E. F., Pan, W. L., and Ng, T. B. (2012). An antifungal peptide from Phaseolus vulgaris cv. brown kidney bean. Acta Biochim. Biophys. Sin. (Shanghai) 44, 307-315. doi: 10.1093/abbs/gms003

Chang, W. K., Wimley, W. C., Searson, P. C., Hristova, K., and Merzlyakov, M. (2008). Characterization of antimicrobial peptide activity by electrochemical impedance spectroscopy. Biochim. Biophys. Acta 1778, 2430-2436. doi: 10.1016/j.bbamem.2008.06.016

Chiantia, S., and London, E. (2013). "Sphingolipids and membrane domains: recent advances," in Handbook of Experimental Pharmacology, eds. E. Gulbins and I. Petrache. (Stony Brook, NY: Springer), 33-55. doi: 10.1007/978-3-7091-1368-4_2

Clardy, J., Fischbach, M. A., and Currie, C. R. (2009). The natural history of antibiotics. Curr. Biol. 19, R437-R441. doi: 10.1016/j.cub.2009.04.001

Daniotti, J. L., and Iglesias-Bartolome, R. (2011). Metabolic pathways and intracellular trafficking of gangliosides. IUBMB Life 63, 513-520. doi: 10.1002/iub.477

da Silva, A. F., Rodrigues, M. L., Farias, S. E., Almeida, I. C., Pinto, M. R., and Barreto-Bergter, E. (2004). Glucosylceramides in Colletotrichum gloeosporioides are involved in the differentiation of conidia into mycelial cells. FEBS Lett. 561 137-143. doi: 10.1016/S0014-5793(04)00156-5

de Coninck, B., Cammue, B. P. A., and Thevissen, K. (2013). Modes of antifungal action and in planta functions of plant defensins and defensin-like peptides. Fungal Biol. Rev. 26, 109-120. doi: 10.1016/j.fbr.2012.10.002

de Medeiros, L. N. (2009). Interação da defensina Psd1 com a monohexosil ceramida (CMH) isolada do fungo Fusarium solani. Doutor em Química Biológica, Universidade Federal do Rio de Janeiro, Rio de Janeiro.

de Medeiros, L. N., Angeli, R., Sarzedas, C. G., Barreto-Bergter, E., Valente, A. P., Kurtenbach, E., et al. (2010). Backbone dynamics of the antifungal Psd1 pea defensin and its correlation with membrane interaction by NMR spectroscopy. Biochim. Biophys. Acta 1798, 105-113. doi: 10.1016/j.bbamem.2009.07.013

De Paula, V. S., Gomes, N. S., Lima, L. G., Miyamoto, C. A., Monteiro, R. Q., Almeida, F. C., et al. (2013). Structural basis for the interaction of human beta-defensin 6 and its putative chemokine receptor CCR2 and breast cancer microvesicles. J. Mol. Biol. 425, 4479-4495. doi: 10.1016/j.jmb.2013.08.001

den Hertog, A. L., van Marle, J., van Veen, H. A., Van't Hof, W., Bolscher, J. G., Veerman, E. C., et al. (2005). Candidacidal effects of two antimicrobial peptides: histatin 5 causes small membrane defects, but LL-37 causes massive disruption of the cell membrane. Biochem. J. 388, 689-695. doi: 10.1042/BJ20042099

den Hertog, A. L., van Marle, J., Veerman, E. C., Valentijn-Benz, M., Nazmi, K., Kalay, H., et al. (2006). The human cathelicidin peptide LL-37 and truncated variants induce segregation of lipids and proteins in the plasma membrane of Candida albicans. Biol. Chem. 387, 1495-1502. doi: 10.1515/BC.2006.187

Domingues, M. M., Silva, P. M., Franquelim, H. G., Carvalho, F. A., Castanho, M. A. R. B., and Santos, N. C. (2014). Antimicrobial protein rBPI-induced surface changes on Gram-negative and Gram-positive bacteria. Nanomedicine (NBM). doi: 10.1016/j.nano.2013.11.002 [Epub ahead of print].

Donald, C. D., Sun, C. Q., Lim, S. D., Macoska, J., Cohen, C., Amin, M. B., et al. (2003). Cancer-specific loss of beta-defensin 1 in renal and prostatic carcinomas. Lab. Invest. 83, 501-505. doi: 10.1097/01.LAB.0000063929.61760.F6

Ehrenstein, G., and Lecar, H. (1977). Electrically gated ionic channels in lipid bilayers. Q. Rev. Biophys. 10, 1-34. doi: 10.1017/S0033583500000123

Enjalbert, B., Smith, D. A., Cornell, M. J., Alam, I., Nicholls, S., Brown, A. J., et al. (2006). Role of the Hogl stress-activated protein kinase in the global transcriptional response to stress in the fungal pathogen Candida albicans. Mol. Biol. Cell 17, 1018-1032. doi: 10.1091/mbc.E05-06-0501

Epand, R. F., Maloy, L., Ramamoorthy, A., and Epand, R. M. (2010). Amphipathic helical cationic antimicrobial peptides promote rapid formation of crystalline states in the presence of phosphatidylglycerol: lipid clustering in anionic membranes. Biophys. J. 98, 2564-2573. doi: 10.1016/j.bpj.2010.03.002

Fadel, V., Bettendorff, P., Herrmann, T., de Azevedo, W. F. Jr., Oliveira, E. B., Yamane, T., et al. (2005). Automated NMR structure determination and disulfide bond identification of the myotoxin crotamine from Crotalus durissus terrificus. Toxicon 46, 759-767. doi: 10.1016/j.toxicon.2005.07.018

Feinstein, M. B., Fernandez, S. M., and Sha'afi, R. I. (1975). Fluidity of natural membranes and phosphatidylserine and ganglioside dispersions. Effect of local anesthetics, cholesterol and protein. Biochim. Biophys. Acta 413, 354-370. doi: 10.1016/0005-2736(75)90121-2

Fisher, M. C., Henk, D. A., Briggs, C. J., Brownstein, J. S., Madoff, L. C., McCraw, S. L., et al. (2012). Emerging fungal threats to animal, plant and ecosystem health. Nature 484, 186-194. doi: 10.1038/nature10947
Fontana, R., Mendes, M. A., de Souza, B. M., Konno, K., Cesar, L. M., Malaspina, O., etal. (2004). Jelleines: a family of antimicrobial peptides from the Royal Jelly of honeybees (Apis mellifera). Peptides 25, 919-928. doi: 10.1016/j.peptides.2004.03.016

Fry, B. G., Roelants, K., Champagne, D. E., Scheib, H., Tyndall, J. D., King, G. F., et al. (2009). The toxicogenomic multiverse: convergent recruitment of proteins into animal venoms. Annu. Rev. Genomics Hum. Genet. 10, 483-511. doi: 10.1146/annurev.genom.9.081307.164356

Funderburg, N., Lederman, M. M., Feng, Z., Drage, M. G., Jadlowsky, J., Harding, C. V., et al. (2007). Human-defensin-3 activates professional antigen-presenting cells via Toll-like receptors 1 and 2. Proc. Natl. Acad. Sci. U.S.A. 104, 18631-18635. doi: 10.1073/pnas.0702130104

Galgóczy, L., Kovács, L., and Vágvölgyi, C. (2010). "Defensin-like antifungal proteins secreted by filamentous fungi," in Current Research, Technology and Education Topics in Applied Microbiology and Microbial Technology, ed. A. Méndez-Vilas (Valladolid: Formatex), 550-559.

Galgóczy, L., Papp, T., Leiter, E., Marx, F., Pocsi, I., and Vagvolgyi, C. (2005). Sensitivity of different zygomycetes to the Penicillium chrysogenum antifungal protein (PAF). J. Basic Microbiol. 45, 136-141. doi: 10.1002/jobm. 200410512

Galgóczy, L., Papp, T., Lukacs, G., Leiter, E., Pocsi, I., and Vagvolgyi, C. (2007). Interactions between statins and Penicillium chrysogenum antifungal protein (PAF) to inhibit the germination of sporangiospores of different sensitive Zygomycetes. FEMS Microbiol. Lett. 270, 109-115. doi: 10.1111/j.1574-6968.2007.00661.x

Galgóczy, L., Papp, T., Pocsi, I., Hegedus, N., and Vagvolgyi, C. (2008). In vitro activity of Penicillium chrysogenum antifungal protein (PAF) and its combination with fluconazole against different dermatophytes. Antonie van Leeuwenhoek 94, 463-470. doi: 10.1007/s10482-008-9263-x

Gambichler, T., Skrygan, M., Huyn, J., Bechara, F. G., Sand, M., Altmeyer, P., et al. (2006). Pattern of mRNA expression of beta-defensins in basal cell carcinoma. BMC Cancer 6:163. doi: 10.1186/1471-2407-6-163

Games, P. D., Dos Santos, I. S., Mello, E. O., Diz, M. S., Carvalho, A. O., de SouzaFilho, G. A., et al. (2008). Isolation, characterization and cloning of a cDNA encoding a new antifungal defensin from Phaseolus vulgaris L. seeds. Peptides 29, 2090-2100. doi: 10.1016/j.peptides.2008.08.008

Gank, K. D., Yeaman, M. R., Kojima, S., Yount, N. Y., Park, H., Edwards, J. E., et al. (2008). SSD1 is integral to host defense peptide resistance in Candida albicans. Eukaryot. Cell 7, 1318-1327. doi: 10.1128/Ec.00402-07

Ganz, T. (2003). The role of antimicrobial peptides in innate immunity. Integr. Comp. Biol. 43, 300-304. doi: 10.1093/Icb/43.2.300

Ganz, T. (2004). Defensins: antimicrobial peptides of vertebrates. C. R. Biol. 327, 539-549. doi: 10.1016/j.crvi.2003.12.007

Ganz, T., and Lehrer, R. I. (1998). Antimicrobial peptides of vertebrates. Curr. Opin. Immunol. 10, 41-44. doi: 10.1016/S0952-7915(98)80029-0

Ganz, T., Selsted, M. E., Szklarek, D., Harwig, S. S. L., Daher, K., Bainton, D. F., et al. (1985). Defensins - natural peptide antibiotics of human-neutrophils. J. Clin. Invest. $76,1427-1435$. doi: $10.1172 /$ Jci1 12120

Gao, B., Rodriguez Mdel, C., Lanz-Mendoza, H., and Zhu, S. (2009). AdDLP, a bacterial defensin-like peptide, exhibits anti-Plasmodium activity. Biochem. Biophys. Res. Commun. 387, 393-398. doi: 10.1016/j.bbrc.2009.07.043

Gao, B., and Zhu, S. (2012). Alteration of the mode of antibacterial action of a defensin by the amino-terminal loop substitution. Biochem. Biophys. Res. Commun. 426, 630-635. doi: 10.1016/j.bbrc.2012.08.143

Gaspar, D., Veiga, A. S., and Castanho, M. A. R. B. (2013). From antimicrobial to anticancer peptides. A review. Front. Microbiol. 4:294. doi: 10.3389/fmicb.2013. 00294

Glaser, R., Harder, J., Lange, H., Bartels, J., Christophers, E., and Schroder, J. M. (2005). Antimicrobial psoriasin (S100A7) protects human skin from Escherichia coli infection. Nat. Immunol. 6, 57-64. doi: 10.1038/ni1142

Gonçalves, J. M., and Polson, A. (1947). The electrophoretic analysis of snake venoms. Arch. of Biochem. 13, 253-259.

Gonçalves, S., Abade, J., Teixeira, A., and Santos, N. C. (2012a). Lipid composition is a determinant for human defensin HNP1 selectivity. Biopolymers 98, 313-321. doi: 10.1002/Bip.22088

Gonçalves, S., Teixeira, A., Abade, J., de Medeiros, L. N., Kurtenbach, E., and Santos, N. C. (2012b). Evaluation of the membrane lipid selectivity of the pea defensin Psd1. Biochim. Biophys. Acta 1818, 1420-1426. doi: 10.1016/j.bbamem.2012.02.012 
Guaní-Guerra, E., Santos-Mendoza, T., Lugo-Reyes, S. O., and Terán, L. M. (2013). Antimicrobial peptides: general overview and clinical implications in human health and disease. Clin. Immunol. 135, 1-11. doi: 10.1016/j.clim.2009. 12.004

Gunn, J. S., Ryan, S. S., Van Velkinburgh, J. C., Ernst, R. K., and Miller, S. I. (2000). Genetic and functional analysis of a PmrA-PmrB-regulated locus necessary for lipopolysaccharide modification, antimicrobial peptide resistance, and oral virulence of Salmonella enterica serovar Typhimurium. Infect. Immun. 68, 6139-6146. doi: 10.1128/IAI.68.11.6139-6146.2000

Guo, M. L., Wei, J. G., Huang, X. H., Huang, Y. H., and Qin, Q. W. (2012). Antiviral effects of beta-defensin derived from orange-spotted grouper (Epinephelus coioides). Fish Shellfish Immunol. 32, 828-838. doi: 10.1016/j.fsi.2012. 02.005

Hagen, S., Marx, F., Ram, A. F., and Meyer, V. (2007). The antifungal protein AFP from Aspergillus giganteus inhibits chitin synthesis in sensitive fungi. Appl. Environ. Microbiol. 73, 2128-2134. doi: 10.1128/AEM.02497-06

Hakomori, S. (2003). Structure, organization, and function of glycosphingolipids in membrane. Curr. Opin. Hematol. 10, 16-24. doi: 10.1097/00062752-20030100000004

Hakomori, S. I. (2008). Structure and function of glycosphingolipids and sphingolipids: recollections and future trends. Biochim. Biophys. Acta 1780, 325-346. doi: 10.1016/j.bbagen.2007.08.015

Halter, D., Neumann, S., van Dijk, S. M., Wolthoorn, J., de Maziere, A. M., Vieira, O. V., et al. (2007). Pre- and post-Golgi translocation of glucosylceramide in glycosphingolipid synthesis. J. Cell Biol. 179, 101-115. doi: 10.1083/jcb.200704091

Hammami, R., Ben Hamida, J., Vergoten, G., and Fliss, I. (2009). PhytAMP: a database dedicated to antimicrobial plant peptides. Nucleic Acids Res. 37, D963D968. doi 10.1093/Nar/Gkn655

Hancock, R. E., and Rozek, A. (2002). Role of membranes in the activities of antimicrobial cationic peptides. FEMS Microbiol. Lett. 206, 143-149. doi 10.1016/S0378-1097(01)00480-3

Hao, X., Yang, H., Wei, L., Yang, S., Zhu, W., Ma, D., et al. (2012). Amphibian cathelicidin fills the evolutionary gap of cathelicidin in vertebrate. Amino Acids 43, 677-685. doi: 10.1007/s00726-011-1116-7

Harder, J., Bartels, J., Christophers, E., and Schroder, J. M. (2001). Isolation and characterization of human beta-defensin-3, a novel human inducible peptide antibiotic. J. Biol. Chem. 276, 5707-5713. doi: 10.1074/jbc.M0085 57200

Hayes, B. M., Bleackley, M. R., Wiltshire, J. L., Anderson, M. A., Traven, A., and van der Weerden, N. L. (2013). Identification and mechanism of action of the plant defensin $\mathrm{NaD} 1$ as a new member of the antifungal drug arsenal against Candida albicans. Antimicrob. Agents Chemother. 57, 3667-3675. doi: 10.1128/AAC 00365-13

Hazlett, L., and Wu, M. (2011). Defensins in innate immunity. Cell Tissue Res. 343, 175-188. doi: 10.1007/s00441-010-1022-4

Hegedus, N., and Marx, F. (2013). Antifungal proteins: more than antimicrobials? Fungal Biol. Rev. 26, 132-145. doi: 10.1016/j.fbr.2012.07.002

Hirsch, T., Spielmann, M., Zuhaili, B., Fossum, M., Metzig, M., Koehler, T., et al. (2009). Human beta-defensin-3 promotes wound healing in infected diabetic wounds. J. Gene Med. 11, 220-228. doi: 10.1002/jgm.1287

Hoover, D. M., Wu, Z., Tucker, K., Lu, W., and Lubkowski, J. (2003). Antimicrobial characterization of human beta-defensin 3 derivatives. Antimicrob. Agents Chemother. 47, 2804-2809. doi: 10.1128/AAC.47.9.2804-2809.2003

Hoskin, D. W., and Ramamoorthy, A. (2008). Studies on anticancer activities of antimicrobial peptides. Biochim. Biophys. Acta 1778, 357-375. doi 10.1016/j.bbamem.2007.11.008

Hwang, J. S., Lee, J., Kim, Y. J., Bang, H. S., Yun, E.Y., Kim, S. R., et al. (2009). Isolation and characterization of a defensin-like peptide (coprisin) from the dung beetle, Copris tripartitus. Int. J. Pept. 2009, 5. doi: 10.1155/2009/136284

Islam, D., Bandholtz, L., Nilsson, J., Wigzell, H., Christensson, B., Agerberth, B., et al. (2001). Downregulation of bactericidal peptides in enteric infections: a novel immune escape mechanism with bacterial DNA as a potential regulator. Nat. Med. 7, 180-185. doi: 10.1038/84627

Jaeger, S. U., Schroeder, B. O., Meyer-Hoffert, U., Courth, L., Fehr, S. N., Gersemann, M., et al. (2013). Cell-mediated reduction of human beta-defensin 1: a major role for mucosal thioredoxin. Mucosal Immunol. 6, 1179-1190. doi: 10.1038/mi.2013.17
Jarczak, J., Kosciuczuk, E. M., Lisowski, P., Strzalkowska, N., Jozwik, A., Horbanczuk, J., et al. (2013). Defensins: natural component of human innate immunity. Hum. Immunol. 74, 1069-1079. doi: 10.1016/j.humimm.2013.05.008

Jha, S., Tank, H. G., Prasad, B. D., and Chattoo, B. B. (2009). Expression of DmAMP1 in rice confers resistance to Magnaporthe oryzae and Rhizoctonia solani. Transgenic Res. 18, 59-69. doi: 10.1007/s11248-008-9196-1

Jiang, Y., Wang, Y., Wang, B., Yang, D., Yu, K., Yang, X., et al. (2010). Antifungal activity of recombinant mouse beta-defensin 3. Lett. Appl. Microbiol. 50, 468-473. doi: 10.1111/j.1472-765X.2010.02824.x

Joly, S., Compton, L. M., Pujol, C., Kurago, Z. B., and Guthmiller, J. M. (2009). Loss of human beta-defensin 1, 2, and 3 expression in oral squamous cell carcinoma. Oral Microbiol. Immunol. 24, 353-360. doi: 10.1111/j.1399-302X.2009.00512.x

Joly, S., Maze, C., McCray, P. B. Jr., and Guthmiller, J. M. (2004). Human betadefensins 2 and 3 demonstrate strain-selective activity against oral microorganisms. J. Clin. Microbiol. 42, 1024-1029. doi: 10.1128/JCM.42.3.1024-1029.2004

Jung, S. I., Finkel, J. S., Solis, N. V., Chaili, S., Mitchell, A. P., Yeaman, M. R., et al. (2013). Bcr1 functions downstream of Ssd1 to mediate antimicrobial peptide resistance in Candida albicans. Eukaryot. Cell 12, 411-419. doi: 10.1128/Ec. 00285-12

Kaiserer, L., Oberparleiter, C., Weiler-Gorz, R., Burgstaller, W., Leiter, E., and Marx, F. (2003). Characterization of the Penicillium chrysogenum antifungal protein PAF. Arch. Microbiol. 180, 204-210. doi: 10.1007/s00203-003-0578-8

Katzung, B. G., Masters, S. B., and Trevor, A. J. (2011). Basic and Clinical Pharmacology. New York: Lange.

Khan, S. A., Fidel, P. L., Jr., Thunayyan, A. A., Varlotta, S., Meiller, T. F., and Jabra-Rizk, M. A. (2013). Impaired Histatin-5 levels and salivary antimicrobial activity against in HIV infected individuals. J. AIDS Clin. Res. 4, 193-198. doi: 10.4172/2155-6113.1000193

Krishnakumari, V., Rangaraj, N., and Nagaraj, R. (2009). Antifungal activities of human beta-defensins HBD-1 to HBD-3 and their C-terminal analogs Phd1 to Phd3. Antimicrob. Agents Chemother. 53, 256-260. doi: 10.1128/Aac. 00470-08

Lacadena, J., Martinez del Pozo, A., Gasset, M., Patino, B., Campos-Olivas, R., Vazquez, C., et al. (1995). Characterization of the antifungal protein secreted by the mould Aspergillus giganteus. Arch. Biochem. Biophys. 324, 273-281. doi: 10.1006/abbi.1995.0040

Ladokhin, A. S., Selsted, M. E., and White, S. H. (1999). CD spectra of indolicidin antimicrobial peptides suggest turns, not polyproline helix. Biochemistry 38, 12313-12319. doi: 10.1021/Bi9907936

Lai, Y. P., and Gallo, R. L. (2009). AMPed up immunity: how antimicrobial peptides have multiple roles in immune defense. Trends Immunol. 30, 131-141. doi: 10.1016/J.It.2008.12.003

Lande, R., Gregorio, J., Facchinetti, V., Chatterjee, B., Wang, Y. H., Homey, B., et al. (2007). Plasmacytoid dendritic cells sense self-DNA coupled with antimicrobial peptide. Nature 449, 564-569. doi: 10.1038/nature06116

Landon, C., Sodano, P., Hetru, C., Hoffmann, J., and Ptak, M. (1997). Solution structure of drosomycin, the first inducible antifungal protein from insects. Protein Sci. 6, 1878-1884. doi: 10.1002/pro.5560060908

Lay, F. T., and Anderson, M. A. (2005). Defensins - components of the innate immune system in plants. Curr. Protein Pept. Sci. 6, 85-101. doi: $10.2174 / 1389203053027575$

Lay, F. T., Mills, G. D., Poon, I. K., Cowieson, N. P., Kirby, N., Baxter, A. A., et al. (2012). Dimerization of plant defensin $\mathrm{NaD} 1$ enhances its antifungal activity. J. Biol. Chem. 287, 19961-19972. doi: 10.1074/jbc.M111.331009

Lay, F. T., Schirra, H. J., Scanlon, M. J., Anderson, M. A., and Craik, D. J. (2003). The three-dimensional solution structure of $\mathrm{NaD} 1$, a new floral defensin from Nicotiana alata and its application to a homology model of the crop defense protein alfAFP. J. Mol. Biol. 325, 175-188. doi: 10.1016/S0022-2836(02)01103-8

Lee, E., Kim, J. K., Shin, S., Jeong, K. W., Shin, A., Lee, J., et al. (2013). Insight into the antimicrobial activities of coprisin isolated from the dung beetle, Copris tripartitus, revealed by structure-activity relationships. Biochim. Biophys. Acta 1828, 271-283. doi: 10.1016/j.bbamem.2012.10.028

Lee, J., Hwang, J. S., Hwang, I. S., Cho, J., Lee, E., Kim, Y., et al. (2012). Coprisin-induced antifungal effects in Candida albicans correlate with apoptotic mechanisms. Free Radic. Biol. Med. 52, 2302-2311. doi: 10.1016/j.freeradbiomed.2012.03.012

Lehrer, R. I. (2004). Primate defensins. Nat. Rev. Microbiol. 2, 727-738. doi: $10.1038 /$ nrmicro976 
Lehrer, R. I., and Ganz, T. (1999). Antimicrobial peptides in mammalian and insect host defence. Curr. Opin. Immunol. 11, 23-27. doi: 10.1016/S09527915(99)80005-3

Lehrer, R. I., and Lu, W. (2011). a-Defensins in human innate immunity. Immunol. Rev. 245, 84-112. doi: 10.1111/j.1600-065X.2011.01082.x

Leipelt, M., Warnecke, D., Zahringer, U., Ott, C., Muller, F., Hube, B., et al. (2001). Glucosylceramide synthases, a gene family responsible for the biosynthesis of glucosphingolipids in animals, plants, and fungi. J. Biol. Chem. 276, 33621-33629. doi: 10.1074/jbc.M104952200

Leiter, E., Szappanos, H., Oberparleiter, C., Kaiserer, L., Csernoch, L., Pusztahelyi, T., et al. (2005). Antifungal protein PAF severely affects the integrity of the plasma membrane of Aspergillus nidulans and induces an apoptosis-like phenotype. Antimicrob. Agents Chemother. 49, 2445-2453. doi: 10.1128/AAC.49.6.24452453.2005

Li, M., Lai, Y. P., Villaruz, A. E., Cha, D. J., Sturdevant, D. E., and Otto, M. (2007). Gram-positive three-component antimicrobial peptide-sensing system. Proc. Natl. Acad. Sci. U.S.A. 104, 9469-9474. doi: 10.1073/pnas.0702159104

Li, P., Chan, H. C., He, B., So, S. C., Chung, Y. W., Shang, Q., et al. (2001). An antimicrobial peptide gene found in the male reproductive system of rats. Science 291, 1783-1785. doi: 10.1126/science.1056545

Li, R., Kumar, R., Tati, S., Puri, S., and Edgerton, M. (2013). Candida albicans Flul-mediated efflux of salivary histatin 5 reduces its cytosolic concentration and fungicidal activity. Antimicrob. Agents Chemother. 57, 1832-1839. doi: 10.1128/Aac.02295-12

Li, S., Du, L., Yuen, G., and Harris, S. D. (2006). Distinct ceramide synthases regulate polarized growth in the filamentous fungus Aspergillus nidulans. Mol. Biol. Cell 17, 1218-1227. doi: 10.1091/mbc.E05-06-0533

Li, Y., Xiang, Q., Zhang, Q., Huang, Y., and Su, Z. (2012). Overview on the recent study of antimicrobial peptides: origins, functions, relative mechanisms and application. Peptides 37, 207-215. doi: 10.1016/j.peptides.2012.07.001

Lobo, D. S., Pereira, I. B., Fragel-Madeira, L., Medeiros, L. N., Cabral, L. M., Faria, J., et al. (2007). Antifungal Pisum sativum defensin 1 interacts with Neurospora crassa cyclin F related to the cell cycle. Biochemistry 46, 987-996. doi: 10.1021/Bi061441j

Madeo, F., Herker, E., Maldener, C., Wissing, S., Lachelt, S., Herlan, M., et al. (2002) A caspase-related protease regulates apoptosis in yeast. Mol. Cell 9, 911-917. doi: 10.1016/S1097-2765(02)00501-4

Maisetta, G., Di Luca, M., Esin, S., Florio, W., Brancatisano, F. L., Bottai, D. etal. (2008). Evaluation of the inhibitory effects of human serum components on bactericidal activity of human beta defensin 3. Peptides 29, 1-6. doi: 10.1016/j.peptides.2007.10.013

Marx, F. (2004). Small, basic antifungal proteins secreted from filamentous ascomycetes: a comparative study regarding expression, structure, function and potential application. Appl. Microbiol. Biotechnol. 65, 133-142. doi: 10.1007/s00253-004-1600-z

Marx, F., Binder, U., Leiter, E., and Pocsi, I. (2008). The Penicillium chrysogenum antifungal protein PAF, a promising tool for the development of new antifungal therapies and fungal cell biology studies. Cell. Mol. Life Sci. 65, 445-454. doi: 10.1007/s00018-007-7364-8

Mayer, F. L., Wilson, D., and Hube, B. (2013). Candida albicans pathogenicity mechanisms. Virulence 4, 119-128. doi: 10.4161/viru.22913

McPhee, J. B., Scott, M. G., and Hancock, R. E. (2005). Design of host defence peptides for antimicrobial and immunity enhancing activities. Comb. Chem. High Throughput Screen. 8, 257-272. doi: 10.2174/1386207053764558

Mehra, T., Koberle, M., Braunsdorf, C., Mailander-Sanchez, D., Borelli, C., and Schaller, M. (2012). Alternative approaches to antifungal therapies. Exp. Dermatol. 21, 778-782. doi: 10.1111/exd.12004

Meiller, T. F., Hube, B., Schild, L., Shirtliff, M. E., Scheper, M. A., Winkler, R., et al. (2009). A novel immune evasion strategy of Candida albicans: proteolytic cleavage of a salivary antimicrobial peptide. PLOS ONE 4:e5039. doi: 10.1371/journal.pone.0005039

Mello, E. O., Ribeiro, S. F., Carvalho, A. O., Santos, I. S., Da Cunha, M., SantaCatarina, C., et al. (2011). Antifungal activity of $P v D 1$ defensin involves plasma membrane permeabilization, inhibition of medium acidification, and induction of ROS in fungi cells. Curr. Microbiol. 62, 1209-1217. doi: 10.1007/s00284-0109847-3

Meyer, V. (2008). A small protein that fights fungi: AFP as a new promising antifungal agent of biotechnological value. Appl. Microbiol. Biotechnol. 78, 17-28. doi: 10.1007/s00253-007-1291-3
Mochon, A. B., and Liu, H. (2008). The antimicrobial peptide histatin-5 causes a spatially restricted disruption on the Candida albicans surface, allowing rapid entry of the peptide into the cytoplasm. PLoS Pathog. 4:e1000190. doi: 10.1371/journal.ppat. 1000190

Mookherjee, N., and Hancock, R. E. W. (2007). Cationic host defence peptides: innate immune regulatory peptides as a novel approach for treating infections. Cell. Mol. Life Sci. 64, 922-933. doi: 10.1007/s00018-007-6475-6

Mor, A., Nguyen, V. H., Delfour, A., Miglioresamour, D., and Nicolas, P. (1991). Isolation, amino-acid-sequence, and synthesis of dermaseptin, a novel antimicrobial peptide of amphibian skin. Biochemistry 30, 8824-8830. doi: 10.1021/Bi00100a014

Moreno, A. B., Del Pozo, A. M., Borja, M., and Segundo, B. S. (2003). Activity of the antifungal protein from Aspergillus giganteus against Botrytis cinerea. Phytopathology 93, 1344-1353. doi: 10.1094/PHYTO.2003.93.11.1344

Moreno, A. B., Martinez Del Pozo, A., and San Segundo, B. (2006). Biotechnologically relevant enzymes and proteins. Antifungal mechanism of the Aspergillus giganteus AFP against the rice blast fungus Magnaporthe grisea. Appl. Microbiol. Biotechnol. 72, 883-895. doi: 10.1007/s00253-006-0362-1

Moreno, M., Segura, A., and Garcia-Olmedo, F. (1994). Pseudothionin-St1, a potato peptide active against potato pathogens. Eur. J. Biochem. 223, 135-139. doi: 10.1111/j.1432-1033.1994.tb18974.x

Morton, C. O., Hayes, A., Wilson, M., Rash, B. M., Oliver, S. G., and Coote, P. (2007). Global phenotype screening and transcript analysis outlines the inhibitory mode(s) of action of two amphibian-derived, alpha-helical, cationic peptides on Saccharomyces cerevisiae. Antimicrob. Agents Chemother. 51, 3948-3959. doi: 10.1128/AAC.01007-07

Mygind, P. H., Fischer, R. L., Schnorr, K. M., Hansen, M. T., Sonksen, C. P., Ludvigsen, S., et al. (2005). Plectasin is a peptide antibiotic with therapeutic potential from a saprophytic fungus. Nature 437, 975-980. doi: 10.1038/nature04051

Nagaoka, I., Niyonsaba, F., Tsutsumi-Ishii, Y., Tamura, H., and Hirata, M. (2008). Evaluation of the effect of human beta-defensins on neutrophil apoptosis. Int. Immunol. 20, 543-553. doi: 10.1093/intimm/dxn012

Nicastro, G., Franzoni, L., de Chiara, C., Mancin, A. C., Giglio, J. R., and Spisni, A. (2003). Solution structure of crotamine, a $\mathrm{Na}^{+}$channel affecting toxin from Crotalus durissus terrificus venom. Eur. J. Biochem. 270, 1969-1979. doi: 10.1046/j.1432-1033.2003.03563.x

Nimrichter, L., Burdick, M. M., Aoki, K., Laroy, W., Fierro, M. A., Hudson, S. A., et al. (2008). E-selectin receptors on human leukocytes. Blood 112, 3744-3752. doi: 10.1182/blood-2008-04-149641

Nimrichter, L., and Rodrigues, M. L. (2011). Fungal glucosylceramides: from structural components to biologically active targets of new antimicrobials. Front. Microbiol. 2:212. doi: 10.3389/fmicb.2011.00212

Niyonsaba, F., Ushio, H., Hara, M., Yokoi, H., Tominaga, M., Takamori, K., etal. (2010). Antimicrobial peptides human beta-defensins and cathelicidin LL-37 induce the secretion of a pruritogenic cytokine IL-31 by human mast cells. J. Immunol. 184, 3526-3534. doi: 10.4049/jimmunol. 0900712

Niyonsaba, F., Ushio, H., Nakano, N., Ng, W., Sayama, K., Hashimoto, K., et al. (2007). Antimicrobial peptides human beta-defensins stimulate epidermal keratinocyte migration, proliferation and production of proinflammatory cytokines and chemokines. J. Invest. Dermatol. 127, 594-604. doi: 10.1038/sj.jid.5700599

Nobile, C. J., and Mitchell, A. P. (2005). Regulation of cell-surface genes and biofilm formation by the C. albicans transcription factor Bcrlp. Curr. Biol. 15, 1150-1155. doi: 10.1016/j.cub.2005.05.047

Noble, S. M., French, S., Kohn, L. A., Chen, V., and Johnson, A. D. (2010) Systematic screens of a Candida albicans homozygous deletion library decouple morphogenetic switching and pathogenicity. Nat. Genet. 42, 590-598. doi: 10.1038/ng.605

Oberparleiter, C., Kaiserer, L., Haas, H., Ladurner, P., Andratsch, M., and Marx, F. (2003). Active internalization of the Penicillium chrysogenum antifungal protein PAF in sensitive aspergilli. Antimicrob. Agents Chemother. 47, 3598-3601. doi: 10.1128/AAC.47.11.3598-3601.2003

Oeemig, J. S., Lynggaard, C., Knudsen, D. H., Hansen, F. T., Norgaard, K. D., Schneider, T., et al. (2012). Eurocin, a new fungal defensin structure, lipid binding, and its mode of action. J. Biol. Chem. 287, 42361-42372. doi: 10.1074/jbc.M112.382028

Olsen, J. G., Flensburg, C., Olsen, O., Bricogne, G., and Henriksen, A. (2004) Solving the structure of the bubble protein using the anomalous sulfur signal 
from single-crystal in-house CuK alpha diffraction data only. Acta Crystallogr. D Biol. Crystallogr. 60, 250-255. doi: 10.1107/S0907444903025927

Oren, Z., Hong, J., and Shai, Y. (1997). A repertoire of novel antibacterial diastereomeric peptides with selective cytolytic activity. J. Biol. Chem. 272, 14643-14649. doi: $10.1074 /$ jbc.272.23.14643

Osborn, R. W., De Samblanx, G. W., Thevissen, K., Goderis, I., Torrekens, S., Van Leuven, F., et al. (1995). Isolation and characterisation of plant defensins from seeds of Asteraceae, Fabaceae, Hippocastanaceae and Saxifragaceae. FEBS Lett. 368, 257-262. doi: 10.1016/0014-5793(95)00666-W

Ouellette, A. J., and Selsted, M. E. (1996). Paneth cell defensins: endogenous peptide components of intestinal host defense. FASEB J. 10, 1280-1289.

Pasupuleti, M., Schmidtchen, A., and Malmsten, M. (2012). Antimicrobial peptides: key components of the innate immune system. Crit. Rev. Biotechnol. 32, 143-171. doi: 10.3109/07388551.2011.594423

Pazgier, M., Hoover, D. M., Yang, D., Lu, W., and Lubkowski, J. (2006). Human betadefensins. Cell. Mol. Life Sci. 63, 1294-1313. doi: 10.1007/s00018-005-5540-2

Pinto, M. R., Rodrigues, M. L., Travassos, L. R., Haido, R. M., Wait, R., and BarretoBergter, E. (2002). Characterization of glucosylceramides in Pseudallescheria boydii and their involvement in fungal differentiation. Glycobiology 12, 251-260. doi: $10.1093 /$ glycob/12.4.251

Porter, E. M., van Dam, E., Valore, E. V., and Ganz, T. (1997). Broad-spectrum antimicrobial activity of human intestinal defensin 5. Infect. Immun. 65, 23962401.

Ramamoorthy, V., Cahoon, E. B., Li, J., Thokala, M., Minto, R. E., and Shah, D. M. (2007a). Glucosylceramide synthase is essential for alfalfa defensin-mediated growth inhibition but not for pathogenicity of Fusarium graminearum. Mol. Microbiol. 66, 771-786. doi: 10.1111/j.1365-2958.2007. 05955.x

Ramamoorthy, V., Zhao, X., Snyder, A. K., Xu, J. R., and Shah, D. M. (2007b). Two mitogen-activated protein kinase signalling cascades mediate basal resistance to antifungal plant defensins in Fusarium graminearum. Cell. Microbiol. 9, 14911506. doi: 10.1111/j.1462-5822.2006.00887.x

Reddy, K. V., Yedery, R. D., and Aranha, C. (2004). Antimicrobial peptides: premises and promises. Int. J. Antimicrob. Agents 24, 536-547. doi: 10.1016/j.ijantimicag.2004.09.005

Ren, Q., Li, M., Zhang, C. Y., and Chen, K. P. (2011). Six defensins from the triangleshell pearl mussel Hyriopsis cumingii. Fish Shellfish Immunol. 31, 1232-1238. doi: 10.1016/j.fsi.2011.07.020

Rittershaus, P. C., Kechichian, T. B., Allegood, J. C., Merrill, A. H. Jr., Hennig, M., and Luberto, C., et al. (2006). Glucosylceramide synthase is an essential regulator of pathogenicity of Cryptococcus neoformans. J. Clin. Invest. 116, 1651-1659. doi: 10.1172/JCI27890

Rodrigues, M. L., Shi, L., Barreto-Bergter, E., Nimrichter, L., Farias, S. E., Rodrigues, E. G., et al. (2007). Monoclonal antibody to fungal glucosylceramide protects mice against lethal Cryptococcus neoformans infection. Clin. Vaccine Immunol. 14, 1372-1376. doi: 10.1128/CVI.00202-07

Sagaram, U. S., Pandurangi, R., Kaur, J., Smith, T. J., and Shah, D. M. (2011). Structure-activity determinants in antifungal plant defensins MsDef1 and $M t$ Def4 with different modes of action against Fusarium graminearum. PLoS ONE 6:e18550. doi: 10.1371/journal.pone.0018550

Sahl, H. G., Pag, U., Bonness, S., Wagner, S., Antcheva, N., and Tossi, A. (2005). Mammalian defensins: structures and mechanism of antibiotic activity. J. Leukoc. Biol. 77, 466-475. doi: 10.1189/Jlb.0804452

Saito, K., Takakuwa, N., Ohnishi, M., and Oda, Y. (2006). Presence of glucosylceramide in yeast and its relation to alkali tolerance of yeast. Appl. Microbiol. Biotechnol. 71, 515-521. doi: 10.1007/s00253-005-0187-3

Salahinejad, E., Hadianfard, M. J., Macdonald, D. D., Sharifi Asl, S., Mozafari, M., Walker, K. J., et al. (2013). Surface modification of stainless steel orthopedic implants by sol-gel ZrTiO4 and ZrTiO4-PMMA coatings. J. Biomed. Nanotechnol. 9, 1327-1335. doi: 10.1166/jbn.2013.1619

Saputo, S., Chabrier-Rosello, Y., Luca, F. C., Kumar, A., and Krysan, D. J. (2012). The RAM network in pathogenic fungi. Eukaryot. Cell 11, 708-717. doi: 10.1128/EC.00044-12

Schneider, T., Kruse, T., Wimmer, R., Wiedemann, I., Sass, V., Pag, U., et al. (2010). Plectasin, a fungal defensin, targets the bacterial cell wall precursor lipid II. Science 328, 1168-1172. doi: 10.1126/science. 1185723

Schroder, J. M., and Harder, J. (1999). Human beta-defensin-2. Int. J. Biochem. Cell Biol. 31, 645-651. doi: 10.1016/S1357-2725(99)00013-8
Schroeder, B. O., Wu, Z., Nuding, S., Groscurth, S., Marcinowski, M., Beisner, J., et al. (2011). Reduction of disulphide bonds unmasks potent antimicrobial activity of human beta-defensin 1. Nature 469, 419-423. doi: 10.1038/nature09674

Scott, M. G., Davidson, D. J., Gold, M. R., Bowdish, D., and Hancock, R. E. (2002). The human antimicrobial peptide LL-37 is a multifunctional modulator of innate immune responses. J. Immunol. 169, 3883-3891.

Segura, A., Moreno, M., Madueno, F., Molina, A., and Garcia-Olmedo, F. (1999). Snakin-1, a peptide from potato that is active against plant pathogens. Mol. Plant. Microbe Interact. 12, 16-23. doi: 10.1094/MPMI.1999.12.1.16

Segura, A., Moreno, M., Molina, A., and Garcia-Olmedo, F. (1998). Novel defensin subfamily from spinach (Spinacia oleracea). FEBS Lett. 435, 159-162. doi: 10.1016/S0014-5793(98)01060-6

Seibold, M., Wolschann, P., Bodevin, S., and Olsen, O. (2011). Properties of the bubble protein, a defensin and an abundant component of a fungal exudate. Peptides 32, 1989-1995. doi: 10.1016/j.peptides.2011.08.022

Semple, F., and Dorin, J. R. (2012). $\beta$-Defensins: multifunctional modulators of infection, inflammation and more? J. Innate Immun. 4, 337-348. doi: $10.1159 / 000336619$

Semple, F., Webb, S., Li, H. N., Patel, H. B., Perretti, M., Jackson, I. J., et al. (2010). Human beta-defensin 3 has immunosuppressive activity in vitro and in vivo. Eur. J. Immunol. 40, 1073-1078. doi: 10.1002/eji.200940041

Shai, Y. (2002). Mode of action of membrane active antimicrobial peptides. Biopolymers 66, 236-248. doi: 10.1002/bip.10260

Shi, J., Aono, S., Lu, W., Ouellette, A. J., Hu, X., Ji, Y., et al. (2007). A novel role for defensins in intestinal homeostasis: regulation of IL-1beta secretion. J. Immunol. 179, 1245-1253.

Silverstein, K. A., Moskal, W. A. Jr., Wu, H. C., Underwood, B. A., Graham, M. A., Town, C. D., et al. (2007). Small cysteine-rich peptides resembling antimicrobial peptides have been under-predicted in plants. Plant J. 51, 262-280. doi: 10.1111/j.1365-313X.2007.03136.x

Smith, J. J., Hill, J. M., Little, M. J., Nicholson, G. M., King, G. F., and Alewood, P. F. (2011). Unique scorpion toxin with a putative ancestral fold provides insight into evolution of the inhibitor cystine knot motif. Proc. Natl. Acad. Sci. U.S.A. 108, 10478-10483. doi: 10.1073/pnas. 1103501108

Song, Y., Cheon, S. A., Lee, K. E., Lee, S. Y., Lee, B. K., Oh, D. B., et al. (2008). Role of the RAM network in cell polarity and hyphal morphogenesis in Candida albicans. Mol. Biol. Cell 19, 5456-5477. doi: 10.1091/mbc.E08-03-0272

Spelbrink, R. G., Dilmac, N., Allen, A., Smith, T. J., Shah, D. M., and Hockerman, G. H. (2004). Differential antifungal and calcium channel-blocking activity among structurally related plant defensins. Plant Physiol. 135, 2055-2067. doi: 10.1104/pp.104.040873

Staubach, S., and Hanisch, F. G. (2011). Lipid rafts: signaling and sorting platforms of cells and their roles in cancer. Expert Rev. Proteomics 8, 263-277. doi: 10.1586/epr.11.2

Steinstraesser, L., Kraneburg, U., Jacobsen, F., and Al-Benna, S. (2010). Host defense peptides and their antimicrobial-immunomodulatory duality. Immunobiology 216, 322-333. doi: 10.1016/j.imbio.2010.07.003

Stotz, H. U., Spence, B., and Wang, Y. (2009). A defensin from tomato with dual function in defense and development. Plant Mol. Biol. 71, 131-143. doi: 10.1007/s11103-009-9512-Z

Sun, J. Y., Gaudet, D. A., Lu, Z. X., Frick, M., Puchalski, B., and Laroche, A. (2008). Characterization and antifungal properties of wheat nonspecific lipid transfer proteins. Mol. Plant. Microbe Interact. 21, 346-360. doi: 10.1094/MPMI-21-30346

Szafranski-Schneider, E., Swidergall, M., Cottier, F., Tielker, D., Roman, E., Pla, J., etal. (2012). Msb2 shedding protects Candida albicans against antimicrobial peptides. PLoS Pathog. 8:e1002501. doi: 10.1371/journal.ppat. 1002501

Tavares, P. M., Thevissen, K., Cammue, B. P. A., Francois, I. E. J. A., BarretoBergter, E., Taborda, C. P., et al. (2008). In vitro activity of the antifungal plant defensin RsAFP2 against Candida isolates and its in vivo efficacy in prophylactic murine models of candidiasis. Antimicrob. Agents Chemother. 52, 4522-4525. doi: 10.1128/Aac.00448-08

Taylor, K., Clarke, D. J., McCullough, B., Chin, W., Seo, E., Yang, D., et al. (2008). Analysis and separation of residues important for the chemoattractant and antimicrobial activities of beta-defensin 3. J. Biol. Chem. 283, 6631-6639. doi: 10.1074/jbc.M709238200 
Terras, F. R., Schoofs, H. M., De Bolle, M. F., Van Leuven, F., Rees, S. B., Vanderleyden, J., et al. (1992). Analysis of two novel classes of plant antifungal proteins from radish (Raphanus sativus L.) seeds. J. Biol. Chem. 267, 15301-15309.

Theis, T., Wedde, M., Meyer, V., and Stahl, U. (2003). The antifungal protein from Aspergillus giganteus causes membrane permeabilization. Antimicrob. Agents Chemother. 47, 588-593. doi: 10.1128/AAC.47.2.588-593.2003

Thevissen, K., Cammue, B. P., Lemaire, K., Winderickx, J., Dickson, R. C., Lester, R. L., et al. (2000a). A gene encoding a sphingolipid biosynthesis enzyme determines the sensitivity of Saccharomyces cerevisiae to an antifungal plant defensin from dahlia (Dahlia merckii). Proc. Natl. Acad. Sci. U.S.A. 97, 9531-9536. doi: 10.1073/pnas.160077797

Thevissen, K., Osborn, R. W., Acland, D. P., and Broekaert, W. F. (2000b). Specific binding sites for an antifungal plant defensin from dahlia (Dahlia merckii) on fungal cells are required for antifungal activity. Mol. Plant Microbe Interact. 13, 54-61. doi: 10.1094/MPMI.2000.13.1.54

Thevissen, K., Ferket, K. K., Francois, I. E., and Cammue, B. P. (2003a). Interactions of antifungal plant defensins with fungal membrane components. Peptides 24 1705-1712. doi: 10.1016/j.peptides.2003.09.014

Thevissen, K., Francois, I. E., Takemoto, J. Y., Ferket, K. K., Meert, E. M., and Cammue, B. P. (2003b). DmAMP1, an antifungal plant defensin from dahlia (Dahlia merckii), interacts with sphingolipids from Saccharomyces cerevisiae. FEMS Microbiol. Lett. 226, 169-173. doi: 10.1016/S0378-1097(03)00590-1

Thevissen, K., Osborn, R. W., Acland, D. P., and Broekaert, W. F. (1997). Specific, high affinity binding sites for an antifungal plant defensin on Neurospora crassa hyphae and microsomal membranes. J. Biol. Chem. 272, 32176-32181. doi: 10.1074/jbc.272.51.32176

Thevissen, K., Tavares, P. D., Xu, D. M., Blankenship, J., Vandenbosch, D., IdkowiakBaldys, J., et al. (2012). The plant defensin RsAFP2 induces cell wall stress, septin mislocalization and accumulation of ceramides in Candida albicans. Mol. Microbiol. 84, 166-180. doi: 10.1111/j.1365-2958.2012.08017.x

Thevissen, K., Terras, F. R., and Broekaert, W. F. (1999). Permeabilization of fungal membranes by plant defensins inhibits fungal growth. Appl. Environ. Microbiol. 65, 5451-5458.

Thevissen, K., Warnecke, D. C., Francois, E. J. A., Leipelt, M., Heinz, E., Ott, C., et al (2004). Defensins from insects and plants interact with fungal glucosylceramides. J. Biol. Chem. 279, 3900-3905. doi: 10.1074/jbc.M311165200

Thomma, B. P. H. J., Cammue, B. P. A., and Thevissen, K. (2002). Plant defensins. Planta 216, 193-202. doi: 10.1007/s00425-002-0902-6

Tsai, P. W., Yang, C. Y., Chang, H. T., and Lan, C. Y. (2011). Human antimicrobial peptide LL-37 inhibits adhesion of Candida albicans by interacting with yeast cell-wall carbohydrates. PLoS ONE 6:e17755. doi: 10.1371/journal.pone.0017755

Ulm, H., Wilmes, M., Shai, Y., and Sahl, H. G. (2012). Antimicrobial host defensinsspecific antibiotic activities and innate defense modulation. Front. Immunol. 3:249. doi: 10.3389/fimmu.2012.00249

van der Weerden, N. L., Bleackley, M. R., and Anderson, M. A. (2013). Properties and mechanisms of action of naturally occurring antifungal peptides. Cell. Mol. Life Sci. 70, 3545-3570. doi: 10.1007/s00018-013-1260-1

van der Weerden, N. L., Hancock, R. E., and Anderson, M. A. (2010). Permeabilization of fungal hyphae by the plant defensin $\mathrm{NaD} 1$ occurs through a cell wall-dependent process. J. Biol. Chem. 285, 37513-37520. doi: 10.1074/jbc.M110.134882

van der Weerden, N. L., Lay, F. T., and Anderson, M. A. (2008). The plant defensin, $\mathrm{NaD} 1$, enters the cytoplasm of Fusarium oxysporum hyphae. J. Biol. Chem. 283, 14445-14452. doi: 10.1074/jbc.M709867200

van Dijk, A., Veldhuizen, E. J., and Haagsman, H. P. (2008). Avian defensins. Vet. Immunol. Immunopathol. 124, 1-18. doi: 10.1016/j.vetimm.2007.12.006

Vylkova, S., Jang, W. S., Li, W., Nayyar, N., and Edgerton, M. (2007). Histatin 5 initiates osmotic stress response in Candida albicans via activation of the Hogl mitogen-activated protein kinase pathway. Eukaryot. Cell 6, 1876-1888. doi: 10.1128/EC.00039-07

Wang, D. Y. C., Kumar, S., and Hedges, S. B. (1999). Divergence time estimates for the early history of animal phyla and the origin of plants, animals and fungi. Proc. Biol. Sci. 266, 163-171. doi: 10.1098/rspb.1999.0617

Wang, Y., Hong, J., Liu, X., Yang, H., Liu, R., Wu, J., et al. (2008). Snake cathelicidin from Bungarus fasciatus is a potent peptide antibiotics. PLoS ONE 3:e3217. doi: 10.1371/journal.pone.0003217

Wang, Z. Z., Shi, M., Ye, X. Q., Chen, M. Y., and Chen, X. X. (2013). Identification, characterization and expression of a defensin-like antifungal peptide from the whitefly Bemisia tabaci (Gennadius) (Hemiptera: Aleyrodidae). Insect Mol. Biol. 22, 297-305. doi: 10.1111/imb.12021

Westerhoff, H. V., Zasloff, M., Rosner, J. L., Hendler, R. W., De Waal, A., Vaz Gomes, A., et al. (1995). Functional synergism of the magainins PGLa and magainin-2 in Escherichia coli, tumor cells and liposomes. Eur. J. Biochem. 228, 257-264. doi: 10.1111/j.1432-1033.1995.tb20258.x

Wimley, W. C., and Hristova, K. (2011). Antimicrobial peptides: successes, challenges and unanswered questions. J. Membr. Biol. 239, 27-34. doi: 10.1007/s00232-011-9343-0

Wong, J. H., Ip, D. C., Ng, T. B., Chan, Y. S., Fang, F., and Pan, W. L. (2012). A defensin-like peptide from Phaseolus vulgaris cv. 'King Pole Bean'. Food Chem. 135, 408-414. doi: 10.1016/j.foodchem.2012.04.119

Wu, X., Sun, J., Zhang, G., Wang, H., and Ng, T. B. (2011). An antifungal defensin from Phaseolus vulgaris cv. 'Cloud Bean'. Phytomedicine 18, 104-109. doi: 10.1016/j.phymed.2010.06.010

Wu, Z. B., Hoover, D. M., Yang, D., Boulegue, C., Santamaria, F., Oppenheim, J. J., et al. (2003). Engineering disulfide bridges to dissect antimicrobial and chemotactic activities of human beta-defensin 3. Proc. Natl. Acad. Sci. U.S.A. 100, 8880-8885. doi: 10.1073/pnas.1533186100

Yamane, E. S., Bizerra, F. C., Oliveira, E. B., Moreira, J. T., Rajabi, M., Nunes, G. L. C., et al. (2013). Unraveling the antifungal activity of a South American rattlesnake toxin crotamine. Biochimie 95, 231-240. doi: 10.1016/j.biochi. 2012.09.019

Yamasaki, K., Di Nardo, A., Bardan, A., Murakami, M., Ohtake, T., Coda, A., et al. (2007). Increased serine protease activity and cathelicidin promotes skin inflammation in rosacea. Nat. Med. 13, 975-980. doi: 10.1038/nm1616

Yang, D., Biragyn, A., Kwak, L. W., and Oppenheim, J. J. (2002a). Mammalian defensins in immunity: more than just microbicidal. Trends Immunol. 23, 291296. doi: 10.1016/S1471-4906(02)02246-9

Yang, S. H., Hong, C. Y., and Yu, C. L. (2002b). The stimulatory effects of nasal discharge from patients with perennial allergic rhinitis on normal human neutrophils are normalized after treatment with a new mixed formula of Chinese herbs. Int. Immunopharmacol. 2, 1627-1639. doi: 10.1016/S1567-5769(02)001339

Yang, D., Chen, Q., Hoover, D. M., Staley, P., Tucker, K. D., Lubkowski, J., et al. (2003). Many chemokines including CCL20/MIP-3alpha display antimicrobial activity. J. Leukoc. Biol. 74, 448-455. doi: 10.1189/jlb.0103024

Yang, D., Chertov, O., Bykovskaia, S. N., Chen, Q., Buffo, M. J., Shogan, J., et al. (1999). Beta-defensins: linking innate and adaptive immunity through dendritic and T cell CCR6. Science 286, 525-528. doi: 10.1126/science.286. 5439.525

Yang, L., Weiss, T. M., Lehrer, R. I., and Huang, H. W. (2000). Crystallization of antimicrobial pores in membranes: magainin and protegrin. Biophys. J. 79, 2002-2009. doi: 10.1016/S0006-3495(00)76448-4

Yeaman, M. R., Soldan, S. S., Ghannoum, M. A., Edwards, J. E., Filler, S. G., and Bayer, A. S. (1996). Resistance to platelet microbicidal protein results in increased severity of experimental Candida albicans endocarditis. Infect. Immun. 64, 1379-1384.

Yeaman, M. R., and Yount, N. Y. (2003). Mechanisms of antimicrobial peptide action and resistance. Pharmacol. Rev. 55, 27-55. doi: 10.1124/pr.55.1.2

YiZeng, T., Shuangquan, Z., and Xianming, Q. (1989). Separation, purification of antibacterial CM4 and the research of the structure and character. Sci. China B 32, 473-480.

Yount, N. Y., and Yeaman, M. R. (2005). Immunocontinuum: perspectives in antimicrobial peptide mechanisms of action and resistance. Protein Pept. Lett. 12, 49-67. doi: 10.2174/0929866053405959

Yount, N. Y., and Yeaman, M. R. (2006). Structural congruence among membrane-active host defense polypeptides of diverse phylogeny. Biochim. Biophys. Acta 1758, 1373-1386. doi: 10.1016/j.bbamem.2006. 03.027

Zasloff, M. (2002). Antimicrobial peptides of multicellular organisms. Nature 415, 389-395. doi: 10.1038/415389a

Zhang, Y., Cougnon, F. B., Wanniarachchi, Y. A., Hayden, J. A., and Nolan, E. M. (2013). Reduction of human defensin 5 affords a high-affinity zinc-chelating peptide. ACS Chem. Biol. 8, 1907-1911. doi: 10.1021/cb400340k

Zhang, Y., Lu, W., and Hong, M. (2011). The membrane-bound structure and topology of a human alpha-defensin indicate a dimer pore mechanism for membrane disruption. Biochemistry 49, 9770-9782. doi: 10.1021/bi101512j 
Zhu, S. (2007). Evidence for myxobacterial origin of eukaryotic defensins. Immunogenetics 59, 949-954. doi: 10.1007/s00251-007-0259-x

Zhu, S. Y., and Gao, B. (2013). Evolutionary origin of beta-defensins. Dev. Comp. Immunol. 39, 79-84. doi: 10.1016/j.dci.2012.02.011

Conflict of Interest Statement: The authors declare that the research was conducted in the absence of any commercial or financial relationships that could be construed as a potential conflict of interest.

Received: 14 August 2013; accepted: 21 February 2014; published online: 20 March 2014
Citation: Silva PM, Gonçalves S and Santos NC (2014) Defensins: antifungal lessons from eukaryotes. Front. Microbiol. 5:97. doi: 10.3389/fmicb.2014.00097

This article was submitted to Antimicrobials, Resistance and Chemotherapy, a section of the journal Frontiers in Microbiology.

Copyright (c) 2014 Silva, Gonçalves and Santos. This is an open-access article distributed under the terms of the Creative Commons Attribution License (CC BY). The use, distribution or reproduction in other forums is permitted, provided the original author(s) or licensor are credited and that the original publication in this journal is cited, in accordance with accepted academic practice. No use, distribution or reproduction is permitted which does not comply with these terms. 